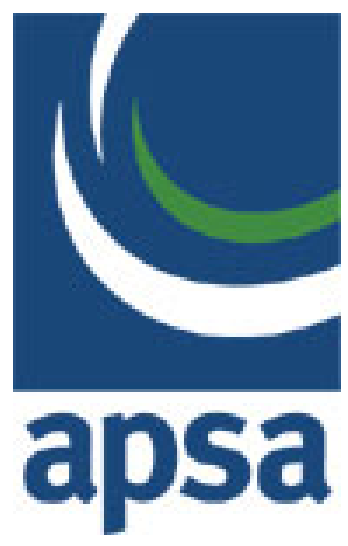

Culture and Preferences in the International Cooperation Two-Step

Author(s): Jeffrey W. Legro

Reviewed work(s):

Source: The American Political Science Review, Vol. 90, No. 1 (Mar., 1996), pp. 118-137

Published by: American Political Science Association

Stable URL: http://www.jstor.org/stable/2082802

Accessed: 20/02/2012 19:46

Your use of the JSTOR archive indicates your acceptance of the Terms \& Conditions of Use, available at http://www.jstor.org/page/info/about/policies/terms.jsp

JSTOR is a not-for-profit service that helps scholars, researchers, and students discover, use, and build upon a wide range of content in a trusted digital archive. We use information technology and tools to increase productivity and facilitate new forms of scholarship. For more information about JSTOR, please contact support@jstor.org. 


\title{
Culture and Preferences in the International Cooperation Two-Step
}

\section{JEFFREY W. LEGRO University of Minnesota}

\begin{abstract}
$R$ ational choice analyses of international cooperation have slighted the effect of state preference formation and the influence of cultural forces in that process. This article addresses these gaps by developing an explanation that specifies how organizational cultures of bureaucracies shape state aims and international outcomes. This approach is evaluated in a set of least likely cases-decisions on the use of force in war-where the conventional wisdom expects external material, not internal cultural, concerns to dominate. Before World War II, countries agreed to limit the use of three types of warfare, but during that conflict mutual restraint was maintained in only one. I show how this variation is best understood as a product of state preference dynamics, shaped largely by the collective beliefs and customs of military services. This result suggests ways to rethink the use of the preferences-interaction model and the role of cultural factors in that framework.
\end{abstract}

I nternational cooperation is more like a tango than a shuffle; its complexities make it difficult to follow. One perspective, rational choice/game theory, has offered a powerful simplifying guide: the "cooperation two-step." One step involves the formation of preferences of actors, the second, interaction among actors that leads to an outcome. Although this framework has offered many insights and shaped much of the study of cooperation, its application has been prone to two types of problems. First, in recent years, the dominant approach to cooperation has neglected preference formation (Jervis 1988) and focused on the interaction of actors attempting to maximize exogenously given preferences. Understanding where preferences come from and how and when they change has received less attention. Second, because the two-step framework is rooted in a rational choice tradition, analysts of cooperation have tended to pay less attention to its cultural determinants. Yet, what is clear is that cultural accounts and the rationalist two-step need not be mutually exclusive, as suggested in different ways by Johnson (1993) and Greif (1994). The implicit claim here is that cultural influence is important and can be usefully studied via traditional social science methodology. (There are, of course, a variety of other insightful ways to think about cultural phenomena.)

This paper highlights both preferences and culture as critical for understanding international cooperation. I offer a domestic-level cultural explanation of preferences that contrasts to the common view that state desires are functionally determined or definitively constrained by the international system. Specifically, I argue that the organizational cultures of government bureaucracies produce information, plans, and capabilities which can constitute state preferences in ways that need not efficiently correspond to international circumstances. Furthermore, I illustrate how preference dynamics, in addition to interaction, can be central to variations in international conflict and cooperation. I

Jeffrey W. Legro is Assistant Professor of Political Science, University of Minnesota, Minneapolis, MN 55455, and for 1995-97, a John M. Olin Fellow, Center for International Affairs, Harvard University, Cambridge, MA 02138

The author is grateful to Marc Busch, Raymond Duvall, Colin Elman, Jeff Frieden, John Freeman, Robert Jervis, Iain Johnston, Ido Oren, Diana Richards, Ronald Rogowski, Richard Rosecrance, and Arthur Stein for their comments and helpful suggestions. examine the importance of culturally shaped preferences in an issue area-the use of force in war-in which the conventional wisdom expects them to be least influential. When national security and survival are at stake, analysts tend to posit interests, emphasize strategic interaction, and discount bureaucratic influence. ${ }^{1}$ Furthermore, cultural influences that may clash with efficient strategic response should fade into the background in the quest for national survival.

Within the category of war, few modern clashes have been as encompassing or intense as World War II, yet states tried to cooperate in limiting the use of certain means of warfare. In the interwar period, lengthy negotiations were aimed at curtailing the development, and especially use in battle, of three stigmatized types: (1) submarine attacks against merchant ships, (2) aerial bombing of nonmilitary targets, and (3) chemical warfare. All three were considered to have both tactical and strategic military utility. During the war, no outside power could act as a referee to control the scale of fighting. The stakes involved "unconditional surrender," and defeat would entail the political, if not literal, extinction of the government. To avoid that outcome, entire industrialized societies devoted themselves to war-making. The cast of characters also did not bode well for limitation, since one of the central decision makers, Hitler, seemed psychotic and incapable of respecting any limitation on force. Yet, during the conflict, different outcomes of restraint and escalation occurred. Submarine warfare was used almost immediately. Strategic bombing was restrained at first and then employed extensively. But chemical weapons, despite expectations and preparations, were never used. How can these variations be deciphered? Why did states choose to cooperate in restraint in some circumstances but not others?

The dominant model of international cooperation would look for answers in factors of strategic interaction (such as time horizons, number of players, communication, and information asymmetries). Furthermore, in such security-threatening circumstances, a unitary na-

\footnotetext{
${ }^{1}$ Many of the seminal strategic interaction studies have focused on decisions on the use of force, either in international crisis or war (for example, Axelrod 1984; Fearon 1995; Jervis 1978; Morrow 1989; Powell 1990; Schelling 1960; Wagner 1991). On interests and bureaucratic influence, see text and notes below.
} 
tional concern is generally assumed to be most influenced by international forces, especially the balance of power. Yet, while interaction dynamics were relevant in World War II, changes in state preferences appear to be the pivotal source of the variation in cooperation-both when it occurred and when it did not. I argue that preference formation was primarily driven by a domestic social and bureaucratic influence, namely, organizational culture, not the balance of power. The cultures of military services, oriented around specific modes of battle, become particularly influential in war, and in World War II these decisively shaped (sometimes by changing, at other times by reinforcing existing) national preferences on the use of force. These preference dynamics were, in turn, central to understanding why cooperation endured in some cases but not others.

This argument suggests that the conventional approach to international cooperation be supplemented in several ways. First, preference formation deserves more analytical and empirical attention than it has been given to date. Second, many, but by no means all, analysts have portrayed security policy preferences as largely a product of the dynamics of survival under anarchy (e.g., Lipson 1985; Mearsheimer 1994/95; Powell 1991), but this has obscured the role of internal determinants, especially in the very unlikely area of the use of force. Here, an explanation based on bureaucratic orientation and influence is offered that differs considerably from existing organizational and bureaucratic models in that it highlights cultural forces. Furthermore, it specifies when and how they will be relevant to state calculations. The aim is not to diminish extant rational choice work but to develop the important overlap between cultural and rational analysis; this is done by illustrating the utility of focusing on collective beliefs and habits in the context of a standard "economic" two-step framework of preferences and interaction.

A necessary starting point is a review of the literature, its treatment of preferences, and its relevance for understanding the cooperation of restraint in World War II. The logic of two alternative approaches to preference formation-organizational culture and realism-are then developed, followed by a discussion of the research design and findings of a test of their relative explanatory power. Finally, the implications of the argument are examined.

\section{THE COOPERATION TWO-STEP}

The implicit conceptualization of cooperation as a twostep process is widespread (for example, Moravcsik 1992; Morrow 1988; Snidal 1986). ${ }^{2}$ As Gordon Tullock (1962) argued years ago, this model suggests that both a science of preferences and a science of interaction are necessary for explaining behavior. Yet, most recent work on cooperation has emphasized interaction considerations. Studies have focused on the number of players,

\footnotetext{
${ }^{2}$ Another common formulation distinguishes between preferences and "constraints," that is circumstances (see, for example, Frieden 1995, Levy 1990). The latter is similar to what I call below strategic interaction or circumstances thereof.
}

the discount rate, and a variety of transactions concerns (such as signalling, information, commitment, monitoring, and sanctioning). ${ }^{3}$ This focus follows the classic economic/game theory model that views preferences as exogenous; they are taken as given, and the analysis begins at that point. Preferences, of course, are still a necessary analytical foundation in that they produce the pay-off matrix that decides what game is being played and whether actors' interests are compatible (Oye 1986), but their origins and evolution are generally left unexplored. ${ }^{4}$ Thus, the model implicitly pushes preferences to the background by focusing on the second step of interaction while assuming the first. As Stigler (1977) and Becker $(1976,5)$ have emphasized, this is often an intentional analytic move to avoid the ad hoc attribution of anomalies, changes in behavior, and so forth, to shifting preferences. But in the study of international cooperation, a bias in the opposite direction is apparent: Variations in cooperation are inevitably seen as a product of changing strategic circumstances. What is also needed is an appreciation for and explanation of preferences. $^{5}$

The problems that can arise in neglecting preference formation are evident in the escalation and restraint of World War II. An explanation that focuses exclusively on interaction while assuming preferences would lead to false conclusions about what mattered in producing the different results in submarine, aerial, and chemical warfare. Both interaction and preferences affected outcomes, but to understand the variation in cooperation, preference dynamics provide crucial leverage. This is so because the most prominent interaction elements of state relations-for example, the number of players, the "shadow of the future," and the ability to make commitments and signal-were similar across the three types of warfare, but the degree of cooperation differed. Yet, the preferences of states, that is, the relative desirability of different outcomes linked to the use (and restraint) of

\footnotetext{
${ }^{3}$ For example, Schelling (1960) sees actors' ability to make credible commitments with one another as central to cooperation. Axelrod (1984) features the shadow of the future or discount rate. Oye (1986) adds to this the number of players, and Martin (1992) singles out the institutional context of bargaining. Rarely does preference formation receive central analytic attention.

4 There are, of course, exceptions; see, for example, Adler 1992, Snyder 1991, Van Evera 1986.

5 Some might argue that it makes sense to assume fixed preferences because some state interests are stable over long periods or are relatively straightforward. Examples of enduring state interests are survival, wealth, and power. But the problem is that these may not be a good guide to desires on specific issues. Many situations are complex, and what can be assumed about preferences is not clear. Consider the mandate of one of the most fundamental goals attributed to states, survival. Political regimes are eliminated without having exhausted their military potential, which illustrates that even so basic an interest as survival need not indicate the preferences a state will have in a particular circumstance, when trade-offs between the desire to protect the population and maintain political autonomy are often considered. In World War II, states certainly maintained interests in survival and security, but these did not translate into consistent preferences on cooperation, as will be seen below.
} 
force, varied. ${ }^{6}$ On the brink of conflict leaders agreed in each of the three areas that cooperation was desirable. During the war, however, states explicitly weighed the desirability of such different outcomes as mutual restraint, one's own unilateral escalation, the opponent's unilateral escalation, and mutual escalation. In a dynamic sense, states generally viewed these as likely to stabilize in one of two outcomes-mutual restraint or mutual escalation. ${ }^{7}$ Thus, a key question is why preferences changed, favoring escalation, or persisted, supporting restraint.

In highlighting preferences, I do not mean to overlook the central insight of the cooperation two-step: Cooperation involves both preference formation and interaction. There was a critical interaction component to cooperation in World War II, because in almost every instance one state's continuing restraint was contingent on the other side's behavior. Nations were not entirely immune to reciprocity. When one side escalated, the other usually followed suit. This basic interactive component of restraint is not captured by an exclusive focus on preferences. But reciprocity was also largely consistent across the three means of warfare, while outcomes varied. Thus, we must turn to preference formation to understand the differences in cooperation in stigmatized warfare in World War II.

\section{THE SOURCES OF STATE PREFERENCES: TWO APPROACHES}

In the study of international cooperation, Tullock's "science" of preferences is relatively underdeveloped, particularly involving serious threats to state security. ${ }^{8}$ If preference formation is considered in such high-threat environments, it is typically seen as a function of the international system. ${ }^{9}$ In comparison, factors internal to states are considered less relevant. When a nation's

\footnotetext{
6 There is a subtle analytical difference between preferences over outcomes and preferences over strategy (Powell 1994, 318). The former refers to the relative desirability to an actor of alternative consequences from a situation, whereas the latter concerns the desirability to an actor of alternative strategies in light of preferences over outcomes and understandings of the other player. The difference is relevant because preferences over outcomes are typically not incorporated into strategic interaction analysis, whereas preferences over strategies can be. In World War II, cooperation (restraint) was both a desired outcome and at times a strategy in the larger "game" of war. ${ }^{7}$ As states recognized at the time (partially due to the norms involved, any escalation in these three forms of warfare would be met with retaliatory escalation. Therefore, since first-use advantages were generally not considered overly significant, it was understood that any unilateral use would quickly result in mutual escalation, and that was the outcome to be evaluated.

${ }^{8}$ In international political economy, the preferences of states have received greater attention. For different conceptualizations, see Frieden 1991, Goldstein 1993, Katzenstein 1978, Lake 1988, Milner 1988, Rogowski 1989. Often the focus in these works is on the preferences of groups within nations, such as firms, factors, or sectors. 9 This is true across a range of schools. For example, a stress on systemic power and advantage is found in Waltz (1979); Keohane (1989) emphasizes systemic institutions; Wendt (1992) highlights the social knowledge and meanings that are collectively held internationally; the epistemic community literature has a transnational aspect (Haas 1992); and Oye (1992) suggests interaction itself conditions state desires. Recent exceptions in security affairs include Snyder (1991) and Kupchan (1994).
}

existence is at stake, interest group politics, class disputes, and bureaucratic battles are expected to be put on hold as countries unite to protect their well-being. Deviations from the national interest produced by organizations or other such forces will be corrected by the intervention of state leaders who pay more attention to security strategy due to the unavoidable external challenge. The central theme is that states inevitably will behave more like unitary actors responding to international circumstances in an effort to maximize relative gains (Grieco 1990; Keohane 1989; Lowi 1969; Mearsheimer 1994/95; Miller 1992; Posen 1984; Powell 1991; Verba 1961; Wolfers 1962).

Several authors have questioned the systemic bias of the study of international cooperation. They argue that domestic factors may be germane to understanding outcomes, particularly in terms of influence on preference formation (Gowa 1986; Haggard and Simmons 1987; Jervis 1988; Milner 1992; Putnam 1988). Such questioning, of course, should not suggest that only domestic-level approaches speak to preference formation and strategy selection. Many systemic-level theories do this, too. These arguments, however, correctly highlight that domestic-level analyses represent a potentially significant alternative or necessary complement to the dominant systemic explanations. But what is clearly required is conceptual and empirical work on the ability of different approaches to account for cooperation and its absence.

This article explores two approaches to explaining preferences on the use of force in World War II. The first, and the one I argue is most persuasive, is organizational culture, a perspective that has received little attention in international relations. The second is based on the prevalent "realist" understanding of state aims and behavior in security affairs. ${ }^{10}$ These two are useful for comparison because they represent different analytical foci, have direct application to the issue at hand, and often provide opposite predictions.

\section{Organizational Culture}

The organizational culture approach asserts that the beliefs and customs embedded in national bureaucracies can determine national aims. Military organizational cultures deserve attention in understanding restraint in war because of the central role the armed forces play in national decisions on the use of force. This cultural view of preference formation emphasizes ideational more than material forces and the internal, rather than external, setting. In the last decade, culture has emerged as a central concept in organizational research, primarily in the field of business management. Analysts dissatisfied with formal structural analysis (which posits that similarly organized businesses will behave similarly) turned to the concept of organizational culture, defined

\footnotetext{
10 Given the historical focus on stigmatized weapons, a third proposition that might be considered is the role of norms and international institutions related to the legitimacy of different types of warfare. Due to space, this is not considered here. For detailed consideration of this proposition, see Legro (1995a, 1995b).
} 
as collectively held assumptions, ideas, and beliefs that prescribe how a group should adapt to its external environment and manage its internal structure (for example, Ouchi and Wilkins 1985; Pedersen and Sorenson 1989; Schein 1985). In recent years there has been a renewed interest in culture in security affairs. ${ }^{11}$ Applied to military bureaucracies, culture is important because it shapes organizational cognition, capabilities, and aims in ways that contradict the expectations of noncultural organizational approaches. In turn, organizational predilection, in certain conditions, can determine state preferences. Two issues, then, are particularly central: (1) the influence of organizational culture on bureaucratic orientation and (2) how bureaucratic priorities shape national preferences and policy.

Culture and Organizational Priorities. Organizational culture can shape organizational priorities and behavior in ways that contradict the expectations of traditional noncultural organizational perspectives based on (1) formal structure or (2) functional purpose. Let me address, first, the difference between a cultural view and one based on structure and, second, differences between cultural and functional perspectives.

One influential view of organizations is based on structure. The assumption of structural organization theory is that similar units within the context of similar structures should exhibit similar behavior. In the literature on militaries and the use of force, the theory predicts that militaries, as similar organizations seeking to maximize autonomy and size and reduce uncertainty, will display common characteristics; they will prefer offensive strategies and resist civilian intervention (Allison 1971; Posen 1984, 1991; Sigal 1988; Snyder 1984; Van Evera 1984, 1986). ${ }^{12}$ Escalation is expected because restraint conflicts with the very nature of autonomyseeking, offense-oriented, war-winning military organizations. While research has indicated that militaries do not always desire war, after the decision for war has been made, professional soldiers value operational autonomy. Once a war is under way, militaries are inclined to use all means at their disposal. Gradualism and restraint can cost lives and are inconsistent with such hallowed principles as concentration of force and the goal of total victory (Betts 1977). The proposition which follows from this logic is that militaries are likely to foster escalation in any usable means of warfare. From a structural organizational perspective, there is little reason to expect any dampening effect on escalation due to organizational influence. Restraint is an anomaly. ${ }^{13}$ But World War II and other conflicts belie this expectation; restraint-aided by the patronage of military organiza-

\footnotetext{
11 For an overview see Johnston (1995a). Organizational culture, or related concepts, also has been used in the literature on bureaucracy. For example, see Halperin (1974) on "essence," Rhodes (1994) on "ideas," and Wilson (1989).

12 For an excellent analysis on the way organizational tendencies need not lead to offensive doctrines due to cultural influence, see Kier (n.d.). 13 Van Evera (1984, chapter 7) presents a detailed case on how the organizational dynamics of militaries favor escalation. Attesting to this expectation are the discussion and examples on organization theory given in Posen (1991, 16-19).
}

tions-did occur. In contrast to the structural approach, a cultural view anticipates that organizations with similar formal structure may have very different understandings, interests, and behavior. Similarly, a cultural view anticipates that the prevailing beliefs in a military can lead to a bias for either escalation or restraint.

A functional view of organizations (one compatible with the realist position outlined below) recognizes that organizations come into being for specific purposes. Accordingly, this view expects that organizations will pursue those purposes in a functional manner in light of environmental circumstances. Thus, military organizations can be expected to use available information and resources to produce as much "security" as possible, adapting to circumstances as they change. In contrast, a cultural view would emphasize the way organizational traits and orientations result not from functional adaptation to the security environment but instead reflect a set of internal collective beliefs and habits that may have little to do with formal purpose or environmental conditions.

Culture shapes organizations in both cognitive and material ways. Cognitively, culture acts as a heuristic for collective perception and calculation, in much the same way a theoretical paradigm can shape intellectual thought (Kuhn 1970) or a schema individual thinking (Khong 1992). Culturally shaped agents tend to discount the environmental data and facts that contradict the existing orthodoxy. Even functional demands to make corrections in order to survive may go unheeded by organizations. Thus, approaches which anticipate that organizations rationally adapt to external circumstances will not be able to explain this shortfall. ${ }^{14}$ The number of large companies that have failed to conform to market forces are legion. And militaries do not consistently adopt war-fighting strategies suited to a given strategic circumstance. ${ }^{15}$ For example, despite organizational efforts (such as military exercises and maneuvers) to test the effectiveness of their ways of war, cultural biases tend to produce conclusions that reinforce, not critically assess, existing beliefs. These biases are reminiscent of the cognitive and motivational distortions discussed in the psychological literature (Jervis 1976; Jervis, Lebow, and Stein 1985; Khong 1992). The difference is that cultural biases are not only based in the information processing capacity or emotions of individuals but also, and most important, in collective understandings.

Culture also has material consequences. Most appar-

\footnotetext{
14 Some theorists suggest that even though organizational cultures or routines may seemingly be inefficient in the short run, they may still be rational. For example, Krasner (1972) suggests that seemingly dysfunctional routines may still make sense given the huge costs involved in reorienting bureaucracies. Kreps (1990) argues that corporate cultures can be very functional in facilitating communication and coordination within organizations. Despite the insights of these explanations, they cannot explain why organizations maintain doctrines that result in massive failures, particularly when information is available that foreshadows such shortcomings and when the costs of adaptation are not prohibitive.

15 One well-known case of this was the persistence of the cavalry into the twentieth century despite the clear demands of the modern battlefield (Katzenbach 1958). Travers (1987) gives example from World War I and Krepinevich (1986) from Vietnam.
} 
ent, it affects the capabilities to which organizations choose to allocate resources. Collective beliefs dictate which enterprises are inherently better and should receive support. Organizations will channel resources to methods suited to culture, which subsequently appear more feasible than those that are incompatible with culture and are deprived of funding and attention. ${ }^{16}$ Thus, culture is a determinant of resource decisions that in later periods tend to reinforce the viability of cultural assumptions regardless of their fit with situational "strategic" circumstances. That is, given a particular set of capabilities, a state's choice may seem "rational" even if the expected results are marginal. But what may be more interesting is why that state came to be limited by such capabilities when other tools could have been easily developed.

Some organizations may be particularly prone to cultural influence. Bureaucracies, for example, often have intangible goals that only become concrete in specific situations or interpretations and usually objective criteria to assess progress are lacking (Wilson 1989). This uncertainty adds to the likelihood that these organizations will focus their efforts around modes or methods of output rather than actual goals. The methods over time take on a symbolic value of their own that may endure even when the demands of efficiency suggest the need for change. Individuals become socialized into, and acquire material interests (such as career advancement) in, certain modes of "doing business." In militaries these modes are styles of fighting war. In effect, collective beliefs about means become the end. And this orientation around beliefs about means leads to an insensitivity to functional adaptation to the environment.

If cultures do not derive from function or environmental pressures, where do they come from and how do they change? While these are large questions that generally lie outside the scope of this study, they deserve attention because of the implication that culture is spurious to some other "cause." My work, however, indicates that organizational culture is not the product of some monocausal force but instead is shaped by many factors, including technology, domestic and international environments, individuals, and accident. Furthermore, these components may themselves interact, allowing for a plethora of aggregate possibilities. The analytical value of focusing on culture is that it can be an autonomous force not easily reducible to the many factors constituting it. To draw an analogy, if we are interested in the effect of a hurricane, we need not always be concerned with the complex atmospheric conditions that give rise to it. The hurricane itself stands out as an identifiable, potent phenomenon that becomes greater than the sum of its parts.

What this study does have to do, however, is demonstrate that culture is not simply spurious to environmental factors such as those emphasized by the alternative explanation of preferences-realism-discussed below. The bulk of my research indicates that culture is often

\footnotetext{
16 This is the "competency trap," in which experience with, and sunk costs in, certain technology or means make them seem better even if others are actually superior (Levitt and March 1988).
}

resilient to external pressures to change, that is, organizational cultures do not functionally adapt, even when the costs and benefits suggest it would make sense to do so. My point is not that militaries never think about results or what the enemy might do; rather, specific organizational orientations shape the valuation of both other actors and potential outcomes to such a degree (and often in conflict with "objective" external circumstances) that it is useful to think of this as an internal cultural occurrence.

What I am arguing here is a tendency, not an absolute. Militaries do adapt, adjust, and even "learn" (e.g., see Rosen 1991; Zisk 1993). This is especially true in stark cases of rapid changes (i.e., "shocks") that dramatically disconfirm the plausibility of existing cultural orientation (see the case of U.S. submarine policy below). Nonetheless, military cultures seem relatively durable, and adaptation is often episodic. There is enough evidence from World War II and other periods in history that militaries do not consistently "learn" (even after losing "battle after battle," such as the United States in Vietnam) to prevent explaining behavior by focusing on adaptation to objective circumstances (Keegan 1993). Thus, despite the possibility of cultural change and the associated difficulties with explaining it, the basic contention of the organizational culture approach is that culture often persists even when in conflict with environmental circumstances.

Organizational Salience and State Preferences. The remaining issue to be explained is how organizational propensity shapes state desires. This has been a weak point in traditional organization theory applied to foreign policy (Art 1973; Krasner 1972). Governments consist of multiple agencies, and the question is which bureaucracies will matter and when. The brief answer offered here is that a bureaucracy's influence varies with its organizational salience, which consists of at least three dimensions: (1) the extent to which it has monopoly power on expertise, (2) the complexity of the issue, and (3) the period available for action. First, when one organization has all the expertise and no competitors, there is less pressure to change, and organizational biases are not checked. Second, the intricacy of an issue affects the degree to which specialist knowledge is required for decisions. The more complex the issue, the less senior authorities can oversee the operations, and the more organizational preferences will be felt. Third, the time frame for decision making can also have an effect. When decision-making cycles are short, there is little time for adjusting prearranged menus. They must be cooked and dished out as planned. All these traits suggest that the military will have a high salience in choices on the use of force in war. Militaries are key players in such situations because they generally have a monopoly on expertise, military operations are complex and not easily understood by nonspecialists, and the time for altering prearranged plans is limited. Although civilians may have authority to make final choices, often contrary to their wishes and intervention, military preferences can prevail in the midst of war due to the organizational salience of the armed forces. This view of 
when military organizations matter is in direct contrast to the dominant thinking on this issue, which posits that when threats to the state are significant, civilian leaders will intervene to correct the organizational biases of the armed forces (see Posen 1984).

In sum, organizational culture is important because it shapes organizational identity, priorities, perception, and capabilities in ways unexpected by noncultural approaches. Those means compatible with the dominant war-fighting culture will be developed and advocated by the military, those that are not will suffer neglect. ${ }^{17}$ Especially in war, military orientations can affect national preferences because of increased organizational salience. Thus, even as the cultural tendencies of subnational organizations remain fairly consistent, their heightened influence in war may lead to change in national preferences (if such preferences are not compatible with culture). Because cultures are embedded in particular military services, we should expect national preferences to vary across issues areas and over time according to the culture and organizational salience of the relevant service.

Proposition 1: States are likely to prefer restraint in a particular combat type when its use is antithetical to the war-fighting culture of their military bureaucracy. Where the organizational cultures of state military bureaucracies are compatible with use, states are more likely to favor escalation.

\section{Realism}

The strategic rationality of realism seems particularly well suited as an alternative to organizational culture for understanding the use of force in a conflict that threatens survival. ${ }^{18}$ This perspective is well known, and only a brief review is provided here. Most generally, realism expects that states will prefer whatever alternative best serves their political and territorial viability in a given situation "under anarchy." As Waltz $(1979,134)$ states, "the appropriate state action is calculated according to the situation in which the state finds itself." Based on a primary state interest of achieving security, preferences on any particular issue are expected as a rule to fit the objective constraints and incentives of the situation. ${ }^{19}$

\footnotetext{
${ }^{17}$ Culture here refers to the beliefs held within a specific military organization. They may or may not relate to wider societal culture or to the beliefs held within a different military organization.

18 I follow the lead of other analysts in my presentation of realism. As with Posen (1984) and Grieco (1990), my portrayal relies on neorealism but pulls it in the direction of classical realism. For recent discussions of realism and cooperation, see Baldwin (1993) and Glaser (1994/95).

19 That is, as these are defined by the balance of power. It is important to note that realism is distinct from a rational actor approach and does have something to add on the formation of preferences. A generic rational actor approach does not specify the sources of utilities that determine preferences. It simply assumes that states will weigh costs and benefits, no matter how they are derived, and select the option that yields the largest net gain. Realism relies on "rational" state action but makes much more specific predictions about what drives utilities. Realism expects state preferences to respond primarily to constraints and opportunities shaped by the balance of power. For example, see the discussion of "National Preferences and International Pressures" in Waltz $(1993,61-70)$.
}

For realists, situation does not refer to class structure, international norms, or the domestic political aims of politicians but to opportunities for relative advantage based on the international distribution of capabilities among states.

Most generally, realism has explained cooperation through balance-of-power theory, which asserts that the tendency of nations toward conflict is only contained by the penalties (such as monetary or physical) that might be incurred by taking on a stronger opponent or coalition. In this view, the primary incentive for states to cooperate is to counter, or "balance" against, a state aspiring to hegemony (Waltz 1979). Realism's logic is, however, applicable to other issues and forms of cooperation than simply the macro-machinations of alliances (Glaser 1994/95). For example, Posen (1984) uses realist reasoning to explain state preferences on military doctrine. And in a study specifically addressing cooperation, Grieco (1990) adopts realism to account for why states do and do not adopt nontariff barriers in trading. For both authors, states' efforts are shaped around the aim of securing their position based on the external constraints and opportunities of relative power.

What would realism anticipate about the likelihood of states showing restraint even as they try to destroy one another? For realists, states are assumed to be concerned with survival and security and will pursue whatever strategy-restraint or escalation-best serves those interests. In the case of war between two states over unconditional surrender, leaders should be particularly concerned about gaining advantages that will aid victory or survival. From this perspective, preferences should follow from opportunities offered by the balance of power. Through the use of peacetime exercises-and the intervention of civilian leaders when militaries are recalcitrant-strategies that take maximum advantage of the given situation should result. With regard to the use of stigmatized weapons, states should prefer outcomes and strategies that make them better off, relative to their adversaries, than they would be otherwise. The balance of forces, tempered by geography and technology, should play a significant role in this calculus. The only deviation from this logic relates to realism's emphasis on regime survival at the expense of all other objectives. Realism anticipates that a state whose existence is imminently threatened will adopt any means that prolong its survival. ${ }^{20}$

Proposition 2: States are likely to desire restraint when the relative security penalties of use outweigh the gains based on the external balance of capabilities. States should prefer escalation when the situation offers advantage over their adversaries or to confront an imminent threat to survival.

\section{ASSESSING THE PROPOSITIONS}

Cooperation in war is the product of two or more states opting for restraint. To understand their choices, the

\footnotetext{
${ }^{20}$ Waltz $(1979,91-92)$. For an excellent discussion of this idea, see Stein $(1990,87-112)$.
} 
unit of analysis of this study is national decision making. This focus is appropriate for two reasons. First, although two countries are needed for restraint, escalation occurs by the decision of a single country. Second, a nationallevel focus is useful for examining preference formation in choices that determine cooperation.

\section{Case Selection}

Within the World War II context, submarines, strategic bombing, and chemical warfare deserve the spotlight because they were the three types of combat, quite distinct from others, that states considered for limitation. These three also are relevant to the aim of assessing the different propositions of organizational culture and realism. In relation to organizational culture, the fit between military beliefs and restraint differed for the three types of warfare both within and among countries. In terms of realism, the balance of external advantage changed between and sometimes within cases. The choice of cases from the same war has the strong advantage of permitting controls for a number of factors. For example, the personalities, the causes of the conflict, the stakes at risk, and the general international setting are the same for all three types of warfare. Within the three categories, a total of eight cases are investigated. In submarine warfare, Germany, Britain, and the United States are examined. In strategic bombing, the focus is on Germany and Britain. In chemical warfare, the analysis considers Britain, Germany, and the Soviet Union. The countries selected were either the central actors in a particular means of warfare or present anomalous situations. ${ }^{21}$ All offer intriguing issues.

\section{Method}

The comparative case method is well suited for studying such complex phenomena as cooperation in war where theories are neither well articulated nor substantiated and the number of cases is small (George 1979; George and McKeown 1985; Tilly 1984). Two types of comparisons are most relevant: why some means of warfare were restricted while others were used and why different countries opted for either the restraint or use of a specific type of combat. The task is to assess which perspective best explains restraint by examining which of the approaches most accurately captures the shaping of preferences on limitation and escalation.

\section{Measuring Variables}

To do this, operational measures of causes and outcomes are required. The two independent variables are represented in the competing propositions derived above. Organizational culture is assessed according to

\footnotetext{
21 These cases are, of course, also useful for examining the two propositions derived from realism and organizational culture. For example, the cases of U.S. strategic bombing (including dropping the atomic bomb) and the use of chemical warfare against Japan are excluded because Japan could not retaliate against the United States in those means of warfare, thus substantially changing the nature of the "realist" calculation.
}

the ideas and beliefs about how to wage war that characterized a particular military bureaucracy. A measure of this culture is developed by reviewing available internal correspondence, planning documents, regulations, exercises, and the memoirs of individual members. These multiple sources provide a composite picture of the hierarchy of legitimate beliefs within an organization. Cultural explanations are often accused of post-hoc tautological explanation: A certain cultural belief can always be found after the fact that explains a given action. Obviously, the definition of culture cannot be based on the effects attributed to culture. Fortunately, organizational cultures, especially military ones, are often quite tangible and can be assessed independent of outcomes. Thus, my organizational cultural approach is neither circular nor "nonfalsifiable." As seen below, the case of U.S. submarine warfare policy illustrates that an organizational culture explanation of restraint can be refuted. Table 1 gives a brief summary of the nature of the different cultures and the predictions they entail for restraint or escalation. I elaborate on these below.

The realist proposition is gauged by the opportunities and constraints that confronted states, particularly with regard to relative advantage in escalation. In view of state aims, did the balance of power in a situation offer a country relative gains or losses in escalating? In some instances, this is a counterfactual exercise in that it identifies an objective situation, one to which a state may not have "correctly" (according to realist logic) adapted. In those cases, I show that, by standards of reasonable judgment, states should have had different preferences given the situation (if realist predictions are accurate). I do this by pointing to available but neglected evidence, to internal arguments about the nature of the situation, to nonrational strategic calculations by states, and to comparisons with judgments made by that state or other states in similar situations. This analysis is not simply one of hindsight. The claim is that, given the information available, states could have known their situation. Table 2 provides a condensed summary of my coding of the balance of advantage, and more information is provided below in the findings.

The dependent variable, outcome, refers to the preferences states had for cooperation (or noncooperation) when facing boundaries on the use of force that were recognized as such by the involved parties. This is assessed by the internal discussions of the wartime leadership regarding its preferred outcome. Although these decision-making bodies were not a unitary actor, they were often small groups that debated and generally reached consensus on desired ends. There is every reason to believe these discussions reflect actual preferences. This means that the preferences identified are not simply "revealed" by behavior but, instead, can be assessed independently. ${ }^{22}$ In practice, there was a relatively close correspondence between preferences and action except in those cases in which states preferred mutual restraint but switched to use in response to the

\footnotetext{
22 The exception here is the Soviet case; due to gaps in the evidence available on internal discussions, I rely to a certain degree on revealed preferences.
} 
TABLE 1. Organizational Culture: Predictions

\begin{tabular}{|c|c|c|c|}
\hline Combat Type & Country & Prediction & Abridged Coding Rationale \\
\hline Submarine warfare & Germany & Use & $\begin{array}{l}\text { The German Navy accorded submarine warfare a central place in } \\
\text { strategy, and the ethos of its U-boat force was based on its } \\
\text { unrestricted trade offensive in World War I. }\end{array}$ \\
\hline Submarine warfare & Britain & Restraint & $\begin{array}{l}\text { The Royal Navy was dominated by a belief in the supremacy of } \\
\text { the battleship; the underwater boat was considered a second- } \\
\text { class tool of combat. During the interwar period, even when } \\
\text { Britain's main expected adversary was Japan, a nation } \\
\text { vulnerable to a submarine campaign, the Royal Navy never } \\
\text { considered an anticommerce submarine strategy. }\end{array}$ \\
\hline Submarine warfare & United States & Restraint & $\begin{array}{l}\text { The U.S. Navy was "battleship-bound" in its thinking during the } \\
\text { interwar period. It gave little thought to an unrestricted } \\
\text { submarine campaign against Japan, its main expected } \\
\text { opponent, despite Japan's vulnerability. }\end{array}$ \\
\hline Strategic bombing & Britain & Use & $\begin{array}{l}\text { The Royal Air Force developed around the "faith" of the efficacy } \\
\text { of strategic bombing, particularly to undermine civilian morale, } \\
\text { a doctrine incompatible with restricted bombing rules. }\end{array}$ \\
\hline Strategic bombing & Germany & Restraint & $\begin{array}{l}\text { Although strategic bombing was considered, a battle-support } \\
\text { mentality largely dominated the Luftwaffe, whose primary role } \\
\text { was seen as contributing to the land and sea campaign. This } \\
\text { combat ideology was better suited to restraint. }\end{array}$ \\
\hline Chemical warfare & Britain & Restraint & $\begin{array}{l}\text { The British Army was a tradition-governed, antitechnology force } \\
\text { that was generally hostile to chemical warfare, particularly } \\
\text { given its institutional experience in World War I. Chemical } \\
\text { warfare was more compatible with the RAF's strategic } \\
\text { bombing thinking, but the Army was in charge of chemical } \\
\text { warfare development; the RAF developed its own biases for } \\
\text { fire-bombing and high explosives (even though gas was } \\
\text { considered a complement, not competitor, to those munitions). }\end{array}$ \\
\hline Chemical warfare & Germany & Restraint & $\begin{array}{l}\text { The German Army's culture favored the efficacy of the mobile } \\
\text { offensive. Chemical warfare was perceived as largely } \\
\text { incompatible with such a campaign. }\end{array}$ \\
\hline Chemical warfare & Soviet Union & Restraint & $\begin{array}{l}\text { Like the Wehrmacht, the Red Army was dominated by a faith in } \\
\text { the offensive. Chemical warfare was seen primarily as a } \\
\text { defensive weapon. }\end{array}$ \\
\hline
\end{tabular}

other side's first use. ${ }^{23}$ Such cases are coded as "restraint" if the state indicated a preference for nonuse. Table 3 provides a summary.

\section{Evidence}

The historical evidence assessed is of two types. First, given the broad nature of the enterprise, I have relied on a range of excellent secondary works about the countries and matters of concern. Despite this wealth of material, some of the phenomena, particularly the role of organizational culture, have not been adequately covered in the literature. Therefore, I have also examined archival sources. ${ }^{24}$

\footnotetext{
23 A second source of divergence between preferences and action was inadvertence. For an analysis of the sources of inadvertent escalation, see Legro (1994).

24 This was conducted in Germany, Great Britain, and the United States. Despite this effort, gaps remain. Either evidence has been destroyed, never existed, or was not found by me. The most substantial shortfall is that Soviet documents on chemical warfare policy remain
}

\section{COOPERATION IN WAR: FINDINGS}

At the beginning of World War II, states vowed to cooperate in restraint in submarine warfare, strategic bombing, and chemical warfare. These pledges represented the preferences of the nations and, for various reasons, the states involved seemed committed to adhering to the limitations. Leaders' expectations of likely restraint in the three areas, both optimistic and pessimistic, were similar. ${ }^{25}$ Yet, once hostilities started, these desires varied, leading to differences in restraint and escalation across the three types of warfare. Why? Both

largely unavailable, despite recent political changes. Nonetheless, a good deal of material on Soviet policy has been uncovered in the German, British, and U.S. archives. Because of the intrinsic interest of that history, the case merits attention.

${ }^{25}$ Thus, for example, it was not the case that countries expected restraint in chemical warfare but not in submarine warfare. In fact, by the discussions and actions of the interwar period, especially the late 1930s, it appeared that the prohibition against unrestricted submarine warfare was more durable than restraints on chemical warfare (Legro 1995b). 


\section{TABLE 2. Realism: Predictions}

\begin{tabular}{|c|c|c|c|}
\hline Combat Type & Country & Prediction & Abridged Coding Rationale \\
\hline Submarine warfare & Germany & Restraint & $\begin{array}{l}\text { In the first six weeks of war, the period critical for decisions on } \\
\text { submarine restrictions, one of Germany's central strategic } \\
\text { objectives was pacifying the United Kingdom. Hitler } \\
\text { recognized unrestricted warfare would antagonize the British. } \\
\text { While Germany did have an advantage in such warfare (Britain } \\
\text { was dependent on sea commerce), it had far too few U-boats } \\
\text { ( } 26 \text { versus an estimated } 300 \text { needed for victory) to have a } \\
\text { decisive effect on Britain's trade. Thus, as the Foreign Ministry } \\
\text { argued, restraint made geopolitical sense. }\end{array}$ \\
\hline Submarine warfare & Britain & Restraint & $\begin{array}{l}\text { As an island nation dependent on commerce and protected by a } \\
\text { surface fleet, Britain was asymmetrically vulnerable to an } \\
\text { unrestricted antitrade submarine campaign; a limited war was } \\
\text { to Britain's advantage. }\end{array}$ \\
\hline Submarine warfare & United States & Use & $\begin{array}{l}\text { The U.S. rival in the Pacific was Japan, an island nation that was } \\
\text { more vulnerable than the United States to unrestricted } \\
\text { submarine warfare. }\end{array}$ \\
\hline Strategic bombing & Britain & Restraint & $\begin{array}{l}\text { Britain, with its more concentrated population and industry and } \\
\text { smaller air force, was more vulnerable to an unrestricted } \\
\text { bombing campaign than was Germany. This was especially } \\
\text { true during the crucial period after Germany occupied France } \\
\text { and the Low Countries. }\end{array}$ \\
\hline Strategic bombing & Germany & Use & $\begin{array}{l}\text { Because Britain was more vulnerable from the air, strategic } \\
\text { bombing might have provided Germany considerable gains, } \\
\text { particularly when it had secured its position in Western Europe } \\
\text { and Hitler realized no political accommodation with Britain was } \\
\text { possible. }\end{array}$ \\
\hline Chemical warfare & Britain & Use & $\begin{array}{l}\text { Particularly after the D-Day invasion, Britain had superior ability } \\
\text { to conduct chemical warfare. According to realist logic, British } \\
\text { preference should have switched to use, but it did not. }\end{array}$ \\
\hline Chemical warfare & Germany & Use & $\begin{array}{l}\text { In the first part of the war, Germany was believed to have } \\
\text { advantages in both the quantity and quality of its chemical } \\
\text { warfare capability. In the latter part of the war Germany } \\
\text { maintained restraint in several situations, particularly the D-Day } \\
\text { invasion, in which gas use might have made a significant } \\
\text { contribution. In these circumstances, if not in Hitler's last-ditch } \\
\text { defense, realism anticipates use. }\end{array}$ \\
\hline Chemical warfare & Soviet Union & Restraint & $\begin{array}{l}\text { The Soviet Union was at a disadvantage in both chemical warfare } \\
\text { technology and preparations for most of the war. Soviet restraint } \\
\text { in the face of imminent defeat in } 1941 \text {, when the use of chemical } \\
\text { warfare would have certainly slowed the German onslaught, is } \\
\text { nonetheless puzzling from a realist perspective. }\end{array}$ \\
\hline
\end{tabular}

realism and organizational culture provide a prima facie account for the variations in preferences evident in World War II. When assessed against actual events, however, the organizational culture perspective offers a better account. In this paper it is not possible to present the full evidence that supports the argument (see Legro 1995a). I can, however, summarize the results, provide a brief synopsis of the cases, and illustrate the dynamics of organizational culture and realism by discussing one case in some detail.

\section{An Overview}

The aggregate findings are presented in the form of $2 \times$ 2 panels collectively displayed in Figure 1 . The place- ment of cases in the boxes follows from the propositions and outcomes. On the vertical axis, each panel depicts the prediction of the theory (either USE or RESTRAINT) for each case. For realism, if a country's position indicated that relative advantage could be gained from escalation, it was placed in the USE category. If the situation was one of disadvantage, the case was placed in the RESTRAINT category. For organizational culture, if the military's preferred way of war did not favor using the means under consideration, it was placed in the RESTRAINT category. If the opposite was true, the case was placed under USE. On the horizontal axis, the preference outcome (mutual USE or mutual RESTRAINT) is given. To distinguish between the effects of preference shifts and strategic interaction on actual policy choice, cases in 


\begin{tabular}{|c|c|c|c|}
\hline Combat Type & Country & Preference & Abridged Coding Rationale \\
\hline Submarine warfare & Germany & Use & $\begin{array}{l}\text { In the first six weeks of war, preferences shifted from limitation } \\
\text { to a no-holds-barred submarine war. }\end{array}$ \\
\hline Submarine warfare & Britain & Restraint & $\begin{array}{l}\text { Restraint in submarine warfare was preferred, even though the } \\
\text { restrictions were eventually dropped after Germany } \\
\text { abandoned restraint. }\end{array}$ \\
\hline Submarine warfare & United States & Use & $\begin{array}{l}\text { The United States desired unlimited submarine warfare from } \\
\text { the beginning of the conflict. }\end{array}$ \\
\hline Strategic bombing & Britain & Use & $\begin{array}{l}\text { A preference for limitation in the air war shifted to a priority on } \\
\text { unrestricted strategic bombing in spring and summer } 1940 .\end{array}$ \\
\hline Strategic bombing & Germany & Restraint & $\begin{array}{l}\text { A mutually limited air campaign was preferred until Germany } \\
\text { turned to unrestricted bombing in Europe in response to } \\
\text { Britain's escalation. }\end{array}$ \\
\hline Chemical warfare & Britain & Restraint & $\begin{array}{l}\text { Mutual restraint in chemical warfare was preferred throughout } \\
\text { the war when confronting actual situations. (Leaders, } \\
\text { however, indicated a contingent preference for unilateral use } \\
\text { in the event of a German invasion.) }\end{array}$ \\
\hline Chemical warfare & Germany & Restraint & $\begin{array}{l}\text { Mutual restraint in chemical warfare was preferred throughout } \\
\text { the war. }\end{array}$ \\
\hline Chemical warfare & Soviet Union & Restraint & The Soviet Union desired restraint throughout the conflict. \\
\hline
\end{tabular}

which countries preferred restraint but escalated in response to the other side's use were coded as RESTRAINT.

To the extent a particular perspective provides a good account of decisions, the cases line up in the northwest (USE-USE) and southeast (RESTRAINT-RESTRAINT) boxes. This implies that a theory would expect a national preference for escalation, and escalation was indeed preferred. Similarly, restraint is predicted, and the outcome was indeed restraint. In most cases, the ultimate strategy choices of states mirrored their preferences. A comparison of the two panels in Figure 1 indicates the explanatory power of organizational culture in these cases. In almost every area, organizational beliefs and desires became national policy. In contrast, the predictions of realism are much more uneven. Often when states were in a position to gain relative advantage by escalating, they favored restraint. Likewise, when nations faced relative losses if escalation occurred, they led the way across the Rubicon.

\section{Case Briefs}

A short summary of how the two propositions relate to the outcomes in each case gives depth to the tables. The summaries are not meant to be definitive, and all the issues involved cannot be fully addressed, but they provide at least a flavor of the analysis.

German Submarine Warfare. German preferences for restraint at the beginning of the war quickly shifted to use in the first six weeks. Realism would predict restraint in this situation. Hitler prohibited unrestricted submarine warfare because one of his top strategic priorities was not to provoke Britain and other countries; such as the United States, into a conflict he hoped could be avoided. Unrestricted U-boat attacks in World War I had brought the United States into the war, a change in the balance of power that led to Germany's defeat. Submarine warfare did offer tactical military advantages against Britain, which was dependent on sea trade, but Germany had only 26 ocean-going U-boats. Karl Dönitz, commander of the force, argued that 300 would be needed for decisive results. Nonetheless, against the advice of the Foreign Ministry, which argued that escalation was strategically irrational, Germany turned to unrestricted submarine warfare before a decision had been reached on whether Britain could be placated. ${ }^{26}$

This switch is fully anticipated by organizational culture. In the German Navy the U-boat force held a respected position and legacy quite different from that of submarine forces in other countries (e.g., Britain and the United States). Furthermore, this force was distinguished by a collective belief in the utility of unrestricted warfare on commerce. Driven by this culture, naval officials promoted a skewed calculation of the relative tactical naval advantage to be derived through unrestricted submarine warfare. Because of the Navy's monopoly role in terms of agenda setting, evaluation, and implementation in sea warfare, organizational information and advice convinced Hitler to authorize unrestricted submarine warfare (despite the insufficient military results expected), thus displacing the political aim of not antagonizing Britain.

\footnotetext{
${ }^{26}$ Memorandum No. 256, from State Secretary Weizsäcker to the Foreign Minister, 14 October 1939, and Memorandum No. 270 by Weizsäcker, 17 October 1939, Documents on German Foreign Policy Series D (1937-1945), Vol. VIII, The War Years, September 4, 1939March 18, 1940 (Washington, DC: US GPO, 1954).
} 


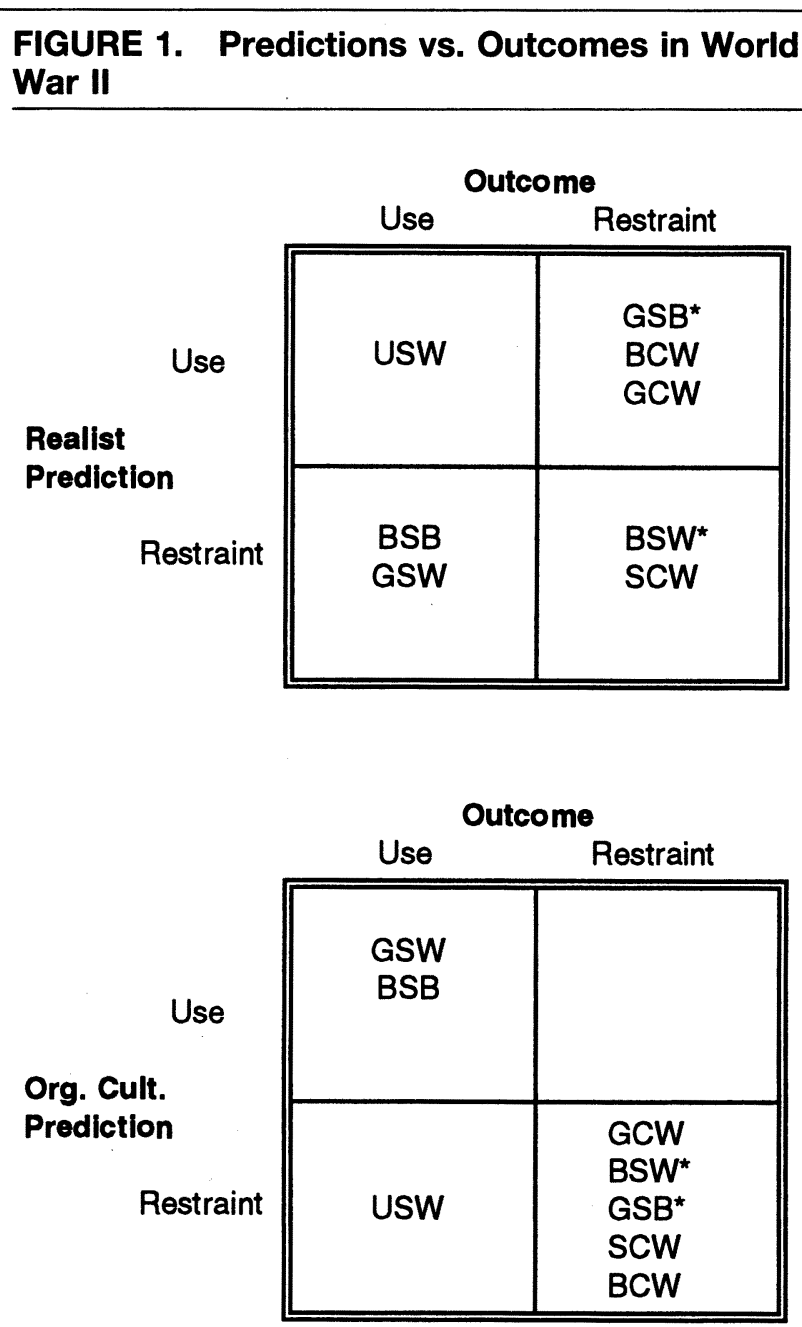

Cases: GSW = German Submarine Warfare; BSW = British Submarine Warfare; USW = U.S. Submarine Warfare; BSB = British Strategic Bombing; GSB = German Strategic Bombing; BCW = British Chemical Warfare; GCW = German Chemical Warfare; SCW = Soviet Chemical Warfare.

* Cases where the country escalated in response to the other side's earlier defection.

British Submarine Warfare. In World War II, Britain desired limitations on submarine warfare, an outcome anticipated by both realism and organizational culture. Realism expects a preference for restraint in this case because Britain was an island nation and more vulnerable to such warfare than Germany. Organizational culture also expects restraint. The British Navy was dominated by an ethos that considered the battleship the pivotal element in the large clashes of fleets which were expected to decide war at sea. The submarine was seen as a strictly ancillary tool, and warfare on commerce, especially the unrestricted type, was paid little heed.

The influence of organizational culture vis-à-vis realism in this case, however, is evident in several situations in which submarine warfare was ignored even though strategic circumstances indicated it would be more efficient than battleship combat. In the interwar period, when Japan-also an island nation vulnerable to a submarine campaign aimed at commerce-was judged
Britain's most likely naval foe, the Royal Navy never seriously considered unrestricted underwater warfare, even though its battleships were inadequate for protecting British interests in the Pacific. During the war, even after Germany had escalated, Britain maintained restraint in situations (e.g., Germany's iron-ore trade with Norway and Sweden and the Axis shipment of supplies across the Mediterranean) in which unrestricted warfare could have provided strategic gains.

U.S. Submarine Warfare. Although mutual restraint in submarine warfare was preferred for most of the interwar period, U.S. preferences changed to favoring unrestricted submarine warfare on the first day of war. Realism persuasively explains this outcome. Japan, like Britain, was asymmetrically vulnerable to an unlimited campaign against its commerce. The United States would gain more than Japan by abandoning cooperation. Realism's emphasis on external circumstances nicely captures the switch in U.S. preferences on the day Japan initiated war with its Pearl Harbor attack.

In contrast, an organizational culture approach would expect restraint. The U.S. Navy, like the Royal Navy, was "battleship-bound" in its thinking during the interwar period. It gave little thought to unrestricted submarine warfare on commerce against Japan, the main expected opponent, despite Japan's vulnerability. The reason culture gave way in this case appears to be tied to the effect of the Pearl Harbor attack on the viability of the battleship culture. With a large portion of the U.S. battleship fleet already sent to the Atlantic to deal with the European war, the Japanese assault destroyed much of the remaining Pacific fleet based in Hawaii. Without battleships, the battleship mentality could not be sustained. The result was a turn to one of the few options remaining-unrestricted submarine warfare.

German Strategic Bombing. Germany's leaders discussed the possibility of attacking Britain's civilian population, but until Britain escalated in the spring and summer of 1940, they preferred mutual restraint. This desire, however, clashed with the strategic opportunities available to Germany. As both combatants believed, Britain was more vulnerable to unrestricted bombing than Germany due to its concentration of population and industry. In addition, Germany had superior strategic position for a bombing campaign after its invasion of France and the Low Countries. Hitler, of course, hoped that Britain would make peace at that time, but even after it was clear Britain would fight on, Germany maintained restraint. ${ }^{27}$

\footnotetext{
27 In both this and the German submarine case, the geostrategic situation indicated that "use" could have provided Germany with military advantages. The different coding on the cases in terms of what realism would predict, however, must depend on the overall politicalmilitary situation when the decisions were made (or not made but should have been). Thus, Germany is coded as restraint under realism in the submarine case because of its strategic aim of pacifying Britain and its small number of submarines at the time the decision for escalation was made. In contrast, German strategic bombing is coded as use because of the advantages Germany had in number of aircraft, demographic/industrial concentration, and geography, and the fact that even though it was clear Britain could not be pacified in summer 1940 (thus, this political aim could not override possible military advantages), Germany maintained restraint.
} 
Organizational culture in this case anticipates restraint. The Luftwaffe, influenced by Germany's continental tradition of warfare and a variety of circumstantial factors, was more focused on contributing to the ground campaign than on achieving victory by undermining enemy morale with an unrestricted bombing offensive. To be sure, strategic bombing was seriously considered in the interwar period in Germany, and it had its advocates during the war. But in the 1930s, the Luftwaffe successively shifted closer to a land campaign support role, and it had insufficient capabilities and plans for the type of strategic air offensive that Britain (as discussed below) had planned to conduct and to confront. This underlying organizational orientation biased Germany in favor of restraint.

British Chemical Warfare. Britain preferred restraint in chemical warfare throughout the war in actual choice situations (even though chemical weapons were considered effective). ${ }^{28}$ Certainly, by the end of the war, realism would have predicted that escalation would have occurred, but it did not. This result is, however, anticipated by organizational culture. Relative to other means, the British Army ignored chemical warfare development because of the institutional legacy (excessive civilian involvement) of World War I use that alienated many officers, an emphasis on regimental tradition that was hostile to technological solutions, and the lack of a definitive mission, which inhibited planning for the use of chemical weapons that were dependent on specific geographical and climatological conditions. Gas use was more compatible with Royal Air Force (RAF) thinking, yet chemical warfare development was in the hands of the Army, and it received little attention or advocacy in the Air Ministry. The RAF recognized a potential role for chemical warfare, but when it appeared that gas development would cut into funding for its preferred tools, i.e., bombing with high explosives and incendiaries, it was willing to forgo the option (even though the choice was not one between more and less effective weapons, since gas and other munitions were seen as complimentary). Churchill was very interested in using chemical warfare, but military organizational predilection resisted change, and no consensus for a shift in national preferences was reached.

German Chemical Warfare. Germany preferred restraint throughout the war. This orientation fits uneasily with realist expectations. Germany's chemical warfare industry, supplies, and war-fighting potential were superior to Britain's at the beginning of the war. Furthermore, even later in the conflict, when Britain's chemical warfare potential had improved, the Wehrmacht could have used chemical weapons in certain situations-most important, the D-Day invasion-for considerable strategic advantage. Surprisingly, a preference for first use of

\footnotetext{
${ }^{28}$ In 1940, however, Britain indicated a preference for first use of chemical warfare in the event that Germany invaded the British Isles This contingent preference is not compatible with either organizational culture or a relative-advantage realist view. It does fit a realist expectation of the use of any means available to inhibit or defer political extinction. Of course, whether Britain actually would have escalated during a German invasion is questionable.
}

chemical warfare did not emerge even as Allied troops crossed into Germany and the survival of the Third Reich was at imminent risk. Organizational culture, however, anticipates restraint. German military beliefs centered around a faith in fast, decisive maneuver and encirclement, which came to be known as blitzkrieg, to reach victory. Chemical warfare was considered best suited for defense, a conception that not did not fit easily with the military's way of thinking. This led Germany to a lack of appreciation for its relative strengths in this area, a neglect toward preparations, and an overall hesitancy to turn to this weapon. A preference for restraint was the result.

Soviet Chemical Warfare. From the historical record available, the Soviet Union also consistently desired restraint in chemical warfare, even when Russia was invaded by Germany and pushed to its very breaking limits at the outskirts of Moscow. Realism captures part of this puzzle. Although Soviet preparations were significant, Red Army troops were caught off guard by the surprise German invasion. The resulting disorganization precluded the possibility of any advantage from initiating chemical warfare. Yet, once the USSR had recovered sufficiently to mount a defense, it is not clear why chemical warfare was not used. After all, persistent poison gas was well suited to Stalin's "scorched earth" strategy, and Soviet survival was at imminent risk. Organizational culture provides a more consistent account. The Red Army was weaned on a philosophy of maneuver and offense, with which chemical warfare was only awkwardly compatible. Thus, like defensive operations as a whole, chemical warfare was neglected and underdeveloped. And the Soviet Union maintained a preference for restraint, despite the incentives to do otherwise.

\section{An Illustrative Case: British Strategic Bombing}

A more in-depth case provides an abbreviated view of several dynamics through which organizational culture was so influential. British strategic bombing is a good focus because of its prominent role in realist analyses (e.g., Quester 1966; Posen 1984). Yet, rather than being a difficult case for organizational culture to explain, it illustrates both how cultures shape organizations and how organizational tendencies-depending on changes in their salience - can lead to changes in national preferences.

In the interwar period, Britain perceived that unrestricted bombing was not in its interests, particularly when Germany appeared as the main challenger. The British population and vital centers (ports, industry, and so forth) were more densely located than was the case in the Third Reich. ${ }^{29}$ Of all cities in Europe, London was

\footnotetext{
29 The British were particularly concerned about the potential threat from German occupation of the Low Countries. Committee for Imperial Defence (CID) Chiefs of Staff (COS) Sub-committee, "The Potential Air Menace to this Country from Germany," 12 June 1934, CAB 53/24, Public Record Office, Kew, England (all documents cited as $\mathrm{CAB}$ can be found in the Cabinet Papers located at the Public Record Office); COS 786, 24 October 1938, as cited in RAF Narrative, The R.A.F. in the Bomber Offensive Against Germany: Vol. I. Pre-War
} 
regarded as one of the most vulnerable to air attack. In 1934 Churchill called the British capital "a tremendous fat cow, a valuable fat cow tied up to attract the beasts of prey" (Spaight 1947, 31). At the beginning of war, Britain, seeing itself as inferior in strategic air capabilities, was delighted to exchange pledges with Germany that neither side would be the first to initiate the bombing of cities and civilians. As long as the RAF's strength was inferior to that of the Luftwaffe, England would not be the first to "take the gloves off." 30

Realism appears vindicated by Britain's preferences based on relative advantage, but this, of course, is not the end of the story. In May 1940, Germany threatened to overrun the Low Countries and France. At the time, Germany was still perceived to have vast superiority in the air. Churchill, recognizing this asymmetry three days before he became prime minister, reflected the consensus in a Cabinet meeting, noting that "it would be very dangerous and undesirable to take the initiative in opening unrestricted air warfare at a time when we possessed only a quarter of the striking power of the German Air Force ... [this] might result in the wholesale indiscriminate bombing of this country." 31 Britain understood that any unilateral escalation on its part would be met in kind by German action. Nonetheless, only eight days later, it was Britain (led by Churchill), not the Luftwaffe, that took the lead in breaking the "no homelands" barrier when it attacked the Ruhr on May 15-16, 1940.32

Why was Britain so willing to escalate the air war given its emphasis on avoiding unrestricted bombing and the acknowledged asymmetry in forces favoring Germany? Realism would focus on the German invasion of the Low Countries and France, confronting Britain with the possible collapse of its most important ally and destruction of the British Army forces on the continent. From this perspective, a change in external circumstances led to an adaptive change in preferences by Britain: The RAF was permitted to carry out the plans that civilians had overseen and approved in the prewar period-the strategic bombing of industrial targets-to confront the invasion. But this argument ignores three key dynamics that do not fit realist logic: (1) the RAF's prewar strategy was not sensibly assessed against external circumstances as realism would expect (until too late in the interwar period); (2) a preference for escalation conflicted with strategic rationality in that Britain's

Evolution of Bomber Command (Air History Branch, Air Ministry), $\mathrm{p}$. 256, AIR 41/39 (all documents cited below as AIR are found in the Air Ministry Papers located at the Public Record Office, Kew, England). 30 War Cabinet, "Air Policy: Memorandum for Communication to the French High Command," 21 October 1939, AIR 14/194, lists factors governing air policy, beginning with "the Allied inferiority vis-à-vis Germany in existing air strengths. From this it follows that for the present the initiative is with Germany; our nation must be conditioned by her action." The "Allies" at this point were Britain and France.

31 Minutes of the War Cabinet (W.M.) (40) 114, Conclusions, Minute 1, 7 May 1940, CAB 65/13.

${ }^{32}$ Here I focus on the first major limitation, no "homelands," in World War II strategic bombing. A second was the "no capital cities" limitation, which Britain transgressed in August 1940. Although strategic rationality played a role in that decision, organizational culture was also central. leaders believed RAF strategic bombing was not suited to fighting Germany and would have costs they considered extremely significant; and (3) Britain critically misinterpreted the external situation at that time by misinterpreting German strategy. All of these deviations from strategic rationality were central to preferences and are best understood as organizational culture effects.

First, while strategic bombing appeared to make sense to Britain as a complement to a naval blockade of Germany in overall strategy, the efficacy of such a plan was accepted uncritically for most of the interwar period. Its feasibility, until too late, was based on excessively optimistic assumptions, which were allowed to stand because they were culturally compatible. While the decision to bomb in May 1940 was consistent with the prewar "Western Air" (WA) plans, the plans themselves were produced by the RAF and therefore guided by its strategic bombing orthodoxy. Most of these options were ill-suited to one of the main expected conflict scenarios, namely, a German invasion across the western borders (Webster and Frankland 1961; Terraine 1985). The failure to adapt plans to circumstances does not fit realist expectations.

Second, during the actual invasion, although the RAF argued for the utility of strategic bombing, British leaders were very hesitant to allow it because they wished to avoid the expected German counterescalation and also because many believed, including the British Army, the French allies, and Churchill himself, that strategic bombing would have little effect on the battlefield and that direct support of the armies was the needed response. ${ }^{33}$ But the RAF lacked the aircraft, skills, and plans to carry out the mission, and its limited efforts at ground support were unsuccessful (Terraine 1985; Tress 1988). Even in light of its limited options, however, Britain made a decision difficult to understand through strategic logic; escalation became the preferred outcome even though it implied significant costs (the dreaded counterattacks) with few benefits (i.e., escalation would not affect the German invasion or save the British Army in France).

Finally, some British leaders reasoned that there was no use in holding back because Germany was expected to escalate the air war anyway, and strategic attacks might relieve the pressure on the battlefield by provoking assaults on Britain. Both of these claims, however, were largely based on the British assumption that the Luftwaffe had a doctrine of strategic bombing similar to that of the RAF (Terraine 1985). This was not accurate. While the German air force did pay attention to strategic bombing, as Murray (1985) has highlighted, it did not dominate the Luftwaffe's thinking as it did in the RAF. German air planning and operations consistently listed the hierarchy of aims as (1) destruction of enemy air power, (2) support of the Army and Navy, and (3) tasks which might be considered strategic bombing. In the 1930s, the Luftwaffe successively shifted closer to a land campaign support role, and it had insufficient capabilities and plans for the type of strategic air offensive that

\footnotetext{
33 WM (40) 114, Conclusions, Minute 1, 7 May 1940, CAB 65/13; Tress (1988, 69-70, 164); and Terraine (1985, 137).
} 
Britain expected. ${ }^{34}$ Thus, the events of spring 1940 raise two questions. Why were the options of British leaders so limited, and why were German air strategy and capabilities so misunderstood?

As suggested above, an important part of the answer to these questions can be found in the organizational culture of the RAF. Virtually from the end of World War I, the RAF was founded and developed according to a philosophy of offensive strategic bombing. The central tenets of this philosophy were that the best way either to prevent or to win a war would be to launch a massive assault on the enemy's sources of power. This included both depriving the enemy of the physical means to fight and breaking its morale to continue the battle. Sir Hugh Trenchard, Chief of the Air Staff (CAS), had no doubt about which was more important: "The moral effect of bombing stands undoubtedly to the material effect in a proportion of 20 to 1" (Jones 1987, 34; Webster and Frankland 1961, 46 and 55). Tactical support of land forces was considered a waste of resources in the RAF mind-set. Trenchard claimed his pilots would be misused if they were to serve merely as "tactical chauffeurs" for the other services (Powers 1976, 167).

This culture, well suited to unrestricted warfare, was engraved on the RAF's personality in a number of ways. One was the selection of personnel. Trenchard was known to have kept on only those officers who agreed with him (Higham 1966). Perhaps more important, institutions were founded that propagated the bomber offensive philosophy, including an air force staff college, a cadet college, and technical training schools. The prominence of the bomber creed should not suggest that there were no dissenters. Cultures are rarely monolithic and often have several sets of beliefs. The RAF had its fighter strategy advocates, and it is not surprising to find that one of the most earnest was Hugh Dowding, Chief of Fighter Command. But the existence of subcultures does not preclude the existence of a dominant orthodoxy with significant disciplinary power. Air Marshal Lord Sholto Douglas, Assistant Chief of the Air Staff in the prewar period, considered his advancement in the RAF as sheer luck: "Anyone who pressed, as I did, the claims of fighters could not escape the charge of heresy" (Douglas 1966, 57; Tress 1988, 49).

The RAF's culture shaped its development. Perhaps this was most evident in the capabilities it acquired. The airmen focused their efforts on planes and equipment designed to support the independent strategic bomber offensive, such as heavy bombers ill-suited for either supporting the Army or precision bombing. Little attention was given to instruments used in close air support or precision attacks. ${ }^{35}$

A second area of cultural influence concerns the

\footnotetext{
${ }^{34}$ See "Weisungen des Oberfehlshabers der Luftwaffe für die Führung des Operationen in der erste Zeit eines Krieges," 18 November 1935, as reprinted in Völker (1968, 445-49); "Aufmarsch- und Kampfanweisungen der Luftwaffe: Weisungen für den Einsatz gegen Osten," Mai 1939, RL 2 II/21, BA-MA; and Führer War Directive \#16, "Preparations for a Landing Operation Against England," 16 July 1940.

${ }_{35}$ One squadron leader protested that the Air Ministry thought dive
}

RAF's "learning" during the interwar period regarding optimal strategy. The experience of World War I, the lessons of which emphasized air superiority by fighter aircraft, had little effect on the bombing-oriented culture (Murray 1992). Furthermore, the airmen uncritically interpreted the events of local wars in the interwar years as confirming the utility of strategic bombing, despite contrary or ambiguous evidence. For example, the experience the British gained using bombers to "police the empire," such as in Iraq in the early 1920s, was taken as proof that the bomber offensive would work in Europe as well, despite the fact that the RAF's opponents in its policing encounters lacked air and ground defenses that European opponents would certainly possess (Webster and Frankland 1961, 60). Even after the German display of the utility of tactical support of ground forces in the Spanish Civil War, the Air Staff refused to recognize the value of the close air support mission (Hallion 1989, 110; Murray 1980, 48). The peacetime exercises, intended as objective measures of effectiveness, did not correct the situation and were often biased to support the validity of the strategic offensive mentality.

In 1930, for instance, Blue Force used a policy of direct attack on the enemy capital while Red Force concentrated on a counter-force campaign. The umpires calculated Blue to have lost 150 bombers, having begun with only 138 ! A Blue staff officer admitted that their effort would have collapsed on the fourth day of the exercise, had the umpires not ruled that the Blue raids on Red cities would have caused a moral collapse on the third night (Smith 1984, 72).

Maneuvers that indicated the "relative impotence rather than power of bombing" were given short shrift. ${ }^{36}$ Strategic bombing plans remained the touchstone of RAF thinking. ${ }^{37}$ Little attention was paid to tactical support. After a 1939 exercise, one air officer noted that pilots were incapable of carrying out a mission supporting ground forces (Murray 1980, 48).

Another area of cultural influence was threat analysis. The RAF tended to attribute to Germany the same bomber-offensive doctrine it held and then use that view to support its own doctrine (Wark 1985). This, of course, led to false notions about Luftwaffe strategy. Even in spring 1940, despite evidence from the Spanish Civil War and the Nazi campaign in Poland of the previous fall, many still believed that only a small part of the Luftwaffe was trained and intended for support of the German army. Those who had different views of the threat were discouraged from voicing them. Intelligence assessments during the Battle of France which suggested that the bombing campaign was working when it was not also reflected cultural biases (Hinsley 1979; Webster and Frankland 1961).

British bombing is a key case distinguishing the relative power of internal-cultural and external-strategic

bombing was a thing of the past. See Minute by Squadron Leader Trgl. to W./Commander Op., 20 October 1938, AIR 14/181.

36 This refers to trials in 1938-1939. See RAF Narrative, Volume I, p. 34, AIR 41/39.

${ }^{37}$ CINC BC, "Readiness for War Report," 10 March 1939, AIR 14/298, suggests WA.5 (which would include attacks on the Ruhr that exceeded Britain's notion of restraint) was the central scheme for planning. 
determinants of strategic policy. For most of the interwar period, the RAF's outlook was largely shaped and developed according to Trenchard's philosophy of strategic offensive bombing. Yet, in 1937, a civilian committee led by Thomas Inskip intervened to impose a fighterbased defense scheme on the RAF. The committee believed that Britain's vulnerability and inferior air power, in light of the growing threat of war (and the cost of the bomber offensive) made a defensive scheme an absolute necessity. RAF policy was apparently turned on its head by civilian dominance (Posen 1984). If the story stopped here, it would certainly illustrate the power of realist over organizational culture factors. But it continues. Within a year of the outbreak of war, the type of unrestricted bomber offensive that Trenchard had envisioned twenty years earlier was implemented. This occurred despite the fact that the external conditions which had prompted increased attention to the defensive scheme in the first place persisted. Britain still perceived itself as extremely vulnerable to air attack and vastly inferior to Germany in air power.

RAF culture, in fact, had not dramatically changed. Development of bomber offensive capabilities was not as rapid as it might have been otherwise, but the strategy was not displaced. In fact, what did not happen is, again, just as telling as what did. The RAF did not shift to an overall fighter-dominated scheme that extended the massive air defense umbrella, used to defend Britain, across the channel to protect the Allied forces on the Continent. Nor did the RAF move to a different type of offensive posture, such as the battlefield-support strategy that emerged in Germany. Instead, the bomber offensive remained the central orthodoxy.

Why did the RAF's culture carry less sway on national choices (i.e., the turn to fighter defenses) in peace yet have a large influence on preferences in war? Here, the concept of organizational salience is insightful. While the military remains the exclusive expert in both peace and war, its influence is more significant during combat, when military affairs (and not, for example, budgets) are the main national concern. In such situations, soldiers often have a say in the highest level decisions of state, and this was true in Britain. In addition, during peace there is often more time to make decisions and change culturally biased plans (even if there is less incentive to do so from a strategic viewpoint, as Posen [1984] notes). Whereas British leaders could to a certain extent redirect resources to fighter command in 1937, there was no way to create a ground attack force instantly in 1940 to take on the German onslaught. Thus, due to the variation in organizational salience, civilian desires were more influential in 1937 than in 1940.

In this case, realism helps explain both Britain's turn to air defense and its restraint in strategic bombing in the first eight months of the war by focusing on Britain's expectation of relative disadvantage from all-out strategic bombing. But realism cannot explain why Britain escalated in 1940 when the same asymmetry in forces still prevailed. This decision makes most sense from an organizational culture perspective on Britain's strategic choices. ${ }^{38}$ RAF culture, emphasizing victory through independent air operations intended to break the enemy's will-power, deemed escalation desirable. The strategic bombing mind-set biased evaluations of effective strategy, expectations of enemy actions, and the capabilities, skills, and plans Britain had available. Thus, when it came time to call the RAF into action, escalation was hard to avoid. Germany's invasion of France coincided with escalation, but it cannot be seen as the main cause of it. In this case, Britain's launching of the unrestricted strategic bomber offensive was more a matter of timing than relative-advantage choice.

\section{IMPLICATIONS}

Useful directions for research in the study of international relations are suggested in three areas: preference formation in cooperation, the sources of foreign policy preferences, and the role of culture in political analysis. Regarding the first, the importance of preference formation and change to cooperation is underscored by the events of World War II. To argue that preferences matter is hardly controversial, but to suggest the appropriateness of focusing on preferences sets my argument apart from two major schools in the study of international relations. One is the predominant extant work on international cooperation that concentrates on interaction. Such analyses have produced significant insights into why and when states collaborate, but their silence on preference dynamics needs to be addressed. Of course, the import of taking preferences as given depends on the theory or model and the purposes for which it is constructed. For example, assuming preferences in formal models that aim to illuminate the logic of interaction rather than empirically test that logic has provided important results, as demonstrated in such work as Robert Powell's (e.g., 1990, 1991). Not surprisingly, Powell suggests that, rather than focus on assumptions about preferences, "careful specifications of the constraints that define the strategic environment will prove the more fruitful and insightful course in future debates" (Grieco, Powell, and Snidal 1993, 737).

The strategic environment, however, cannot be considered the whole story of actual instances of cooperation. To compliment Powell's course, a parallel track is needed that does not debate assumptions over, but pays theoretical and empirical attention to, preferences. Again, I am not suggesting that the differences in use of the three types of warfare is one of "autonomous" preferences: Interaction, as the cooperation two-step suggests, was also critical as seen in the reciprocity of Britain's unrestricted submarine warfare and Germany's unlimited strategic bombing. The broader implication is

38 This case alone does not allow the differentiation of an organizational culture explanation from that of traditional organization theory because both predict use. Where the cultural element is clear, however, is in comparison with Germany. The Luftwaffe had a similar structure and incentives for autonomy, resources, etc. Yet, its air culture was more closely linked to the land campaign that was compatible with restraint. Militaries do not generically favor escalation, as traditional theory expects; the beliefs that characterize similar bureaucracies lead to different orientations on restraint and escalation. 
that there is a need to move beyond static coordination, prisoner's dilemma, or zero-sum games to a richer variety of symmetrical and asymmetrical situations-and most importantly, a consideration of when and why such "games" change.

My argument is also distinct from the second major school, which suggests that we need to concentrate our efforts on the construction of the identities of states (Bloom 1990; Katzenstein n.d.; Nau 1993; Wendt 1992, 1994). Certainly, how states see themselves and their roles can affect both their preferences and actions. Nonetheless, the identities and basic interests of states can remain constant for long periods. Thus, a focus on preferences is useful for exploring why state desires in different issue areas change even as their basic identities remain relatively stable. In short, cooperation in World War II indicates that interaction and identity dynamics must be supplemented by a better understanding of preference formation and change. This requires addressing such issues as the stability of preferences, the sources of preferences, and different ways to think about preferences and interaction that fill in and go beyond the cooperation "two-step." 39

Preference formation is a complex topic, and making sense of the many possible sources of national desires requires alternative approaches and empirical research. This essay has highlighted organizational culture, which shaped preferences in several areas. One is state interpretations of the international situation. The internal beliefs of military organizations molded the way that states understood situations and how they viewed the desirability of different outcomes. Such views were not simply derivative of international conditions. In many instances, cultural preference conflicted with what realism would expect given the external situation. ${ }^{40}$ For example, Britain's air strategy calculations were based on culturally driven conclusions about German strategy and bombing effectiveness that did not match the available evidence. Realists might argue that these deviations simply represent random miscalculation or a failure to grasp accurately the logic of the prevailing balance. But when such behavior is regular across a range of cases ideally suited to realism's logic, such a response holds little water.

Culture also determined the response repertoire available to states. The preparations militaries made in peacetime had a decisive effect on the choices nations made in war. Leaders often faced an option funnel, that is, the variety of policy possibilities was actually limited to the central plan in which organizations had invested themselves. The weapons, plans, and skills developed according to cultural penchant often decided what national leaders would do even before they considered a

\footnotetext{
${ }^{39}$ Ironically, both constructivists and strategic interaction analysts face a similar challenge- how to conceptualize and validate models where preferences are endogenous to intervention while avoiding analytic pitfalls. For examples of each see Finnemore (n.d.) and Oye (1992). 40 While international circumstances did sometimes play a role in the formation of culture (as in the U.S. submarine case), they were not the only formative source. Furthermore, even when international circumstances changed, and the costs of adaptation were not prohibitive, cultures tended to endure.
}

situation. For example, Britain turned to strategic bombing in May 1940 when leaders would have preferred a restricted battlefield support air strategy, but the RAF lacked capabilities for such a mission. This culturecapabilities connection, of course, does not always determine outcomes. The U.S. Navy, after all, shifted rapidly to an unrestricted submarine campaign that it hardly considered during the interwar period. As one commentator has noted, however, it was an "accident of history" that the existing U.S. submarine force could be used for such a strategy-and about one-third of the captains who had trained under the battleship orthodoxy had to be replaced because they simply could not adjust to the new way of thinking (Blair 1975; Rosen 1991).

Another display of organizational influence was in the relative civilian/military imprint on preferences. Realism expects military counsel to be offered but political leaders, unaffected by bureaucratic culture and pressured by imminent threats, should ultimately favor options in line with objective strategic needs (Posen 1984). It was apparent in World War II, however, that civilians did try to alter organizational tendencies but not infrequently either were thwarted or, in the process, changed their own preferences in line with those of the military.41 States learned to want what their armed services had already desired and done.

While organizational culture provides the better overall explanation of the cooperation examined here, realism also offers insights. As it anticipates, leaders set goals, weighed alternative courses of action, and calculated whether benefits outweighed costs. In making choices, ends and means, as they were understood, were often efficiently joined as states sought out relative advantage. At issue is what was considered as an option, what defined costs and benefits, what means were available for implementing choices, and what standard was used in learning from past action or experience. On these crucial issues, states appeared to take their cues more from the internal interpretive world of culture than from the conditions of the external environment, such as the balance of power. This, however, need not always be the case. Depending on the organizational salience of militaries, culture's role may be less. And when cultural orientation clashes dramatically with material feasibility, cultures are more likely to adapt, as in the case of U.S. submarine warfare.

These findings add to the growing body of research that questions the top-down orthodoxy of international relations theory since World War II. Explanations of state security strategies have reflected a significant, probably dominant, concern with systemic determinants that are "outside" states. Many theorists give priority to international constraints, believing that these do the lion's share of explanation, and only move on to other levels to clear up the details that cannot be explained systemically. Deterrence theorists focus on the balance of power and resolve. Regime theorists emphasize systemic agreements and norms. Constructivists point to systemic social interaction. The organizational culture

41 The former applies to British chemical warfare and Churchill; the latter to German submarine policy and Hitler. 
approach, however, suggests that structures and cultures internal to states can be just as constraining, that bottom-up approaches at times can carry the bulk of explanation. Thus, those concerned with whether deterrence succeeds or fails, whether international agreements will be sustained, and whether systemic collective meanings will endure may need to reconsider the way that societal and subsocietal collective beliefs and habits guide the orientation of state knowledge, preferences, and choices undergirding international phenomena.

The challenge of how to weight the relative importance of internal and external approaches is once again apparent. Traditionally, in security affairs and decisions on the use of military force that affect national survival, systemic approaches (particularly realism) have been given pride of place. In contrast, in economic policy, analysts often view domestic interest groups, classes, and sectors as more central. Clearly, the findings here transcend such a division. Furthermore, organizational culture is not only relevant to military bureaucracies or security issues. Although organizational cultures have received relatively little attention in the study of economic policy, some work suggests that they can be important in that area as well (Bachman 1991; Johnson 1982).

The explanatory ability of organizational culture in these cases, however, should not suggest that either culture, organizational influence, or some combination thereof is the most important "domestic" source of preferences. Nor should it suggest that domestic explanations are always, or even usually, more powerful than international systemic ones. The conditions under which the forces in one arena matter more than another, or how the two interact, are clearly an open question. The common refrain that synthetic domestic-international approaches are needed certainly is true. One response to this gap has been the development of the two-level game approach (Evans 1993; Putnam 1988). While this perspective has offered new insights, it replicates the posited preference bias noted above, which assumes actor desires; the innovation is to add different arenas in which state actors strategically attempt to maximize their utility. ${ }^{42}$ Explanations are also necessary to account for the preference and knowledge structures that undergird interaction.

Culture is one important conceptual vehicle for addressing this gap. In international relations theory, culture has generally been poorly applied (Johnston 1995a) or simply relegated to analytical backwaters as a "soft" variable that can only explain marginal residual variance. ${ }^{43}$ Yet, in the "hard" issue area of security affairs and armed conflict, we have seen that one form of culture was quite potent in shaping outcomes. The influence of organizational culture in World War II suggests the applicability of culture for other theories that focus narrowly on "formal" structure-such as the

\footnotetext{
42 This is not to suggest that posited preference approaches do not offer insights, but that these should not become orthodoxy.

${ }^{43}$ This is beginning to change with the recent work of Berger (n.d.), Johnston (1995b), Kier (n.d.), Kupchan (1994), Rosen (1995), and others.
}

distribution of international capabilities, the political structures of states, or the flow chart of organizationsand ignore the "informal" structure of collective beliefs and customs. Formal structure is often inadequate for understanding preferences and behavior. This is true for structural approaches related both to external international position (realism) and internal bureaucratic arrangement (structural organization theory). Structural organization theory, for example, asserts that similar formal structures should have similar preferences and act in a similar manner. Yet, military advocacy of escalation in World War II, as the traditional model expects, was not a uniform response. Organizations favored restraint in certain areas and not in others. These different orientations are best explained by referring to the collective beliefs and customs that characterized and directed the different military services, rather than some generic tendency shared by all military organizations.

Several prominent approaches to international relations based on formal structure might benefit from paying attention to the informal structure of culture. Much of the work on democracies, for example, posits that "republican" regimes will have similar preferences and behavior due to common constitutional structures; e.g., democracies (generically) are less prone to fight one another. A cultural view would suggest that within similar democratic regimes different hierarchies of beliefs can take shape which can lead to different (1) internal norms on cooperation and compromise, (2) perceptions about how others' norms are different from one's own, and, ultimately, (3) external behavior. ${ }^{44}$ For example, a topic worthy of attention is whether norms on cooperation and compromise are really the same in democracies such as the United States, Japan, and Russia and whether officials in those countries perceive them to be the same. A cultural approach suggests caution in assuming that policies of countries need be similar because they have a common political regime type. ${ }^{45}$ At the international level, many explanations generally assume that similar power structures will lead to similar behavior. For example, hegemonic stability theory posits that hegemons will seek an open trading system. The cultural analysis posited here, however, would expect different types of behavior depending on the beliefs and customs that differentiate hegemons. As Ruggie (1982) has noted, despite the similar power structure of Dutch, British, and U.S. hegemony, the nature of the respective international systems differs due to the different collective beliefs that defined the purposes of the hegemons.

My argument is not that structure is unimportant, while culture clears up all puzzles. Rather, it is the combination of culture and structure that matters. Cul-

44 To the extent it is independent of formal constitutional structure, the so-called normative explanation for the democratic peace speaks to this point. Of course, if it is independent of the formal structure of regime type, then one might ask why it is the "democratic" peace. See Maoz and Russett (1993) and Russett (1993).

45 This idea is also relevant for the literature on "strong" and "weak" states; for example, Katzenstein (1978), Krasner (1978), and Evangelista (1988). 
ture's key contribution is to explain how differences in the collective beliefs and norms that characterize structures can lead to different understandings and behavior even while formal structure is similar. Nonetheless, certain measures of formal structural design may be necessary to account for why some cultures are more uniform and influential. As discussed above, the influence of bureaucratic cultures on national policy will vary with their organizational salience. For example, organizations with a functional monopoly (a formal structural trait) are more likely to shape policy than when multiple points of view are available to policymakers. In World War II, the military's organizational monopoly meant that, with no competitors in expertise, military preferences played a large role in decisions on the use of force in terms of advice as well as the types of plans and capabilities developed. Likewise, in other areas in which bureaucracies or societal groups have similar salience, the collective beliefs that characterize them as an entity may be influential. The fact that culture was significant in circumstances of armed conflict, in which material capabilities and strategic action are so critical, suggests that it may be even more relevant in other international relations issues.

\section{REFERENCES}

$\rightarrow$ Adler, Emanuel. 1992. "The Emergence of Cooperation." International Organization 46:101-46.

Allison, Graham T. 1971. Essence of Decision. Boston: Little, Brown.

$\rightarrow$ Art, Robert J. 1973. "Bureaucratic Politics and American Foreign Policy: A Critique." Policy Sciences 4:467-90.

Axelrod, Robert. 1984. The Evolution of Cooperation. New York: Basic Books.

Bachman, David. 1991. Bureaucracy, Economy, and Leadership in China. Cambridge: the University Press.

Baldwin, David A., ed. 1993. Neorealism and Neoliberalism: The Contemporary Debate. New York: Columbia University Press.

Becker, Gary. 1976. The Economic Approach to Human Behavior. Chicago: Chicago University Press.

Berger, Thomas U. N.d. "Norms, Identity, and National Security in Germany and Japan." In The Culture of National Security, ed. Pete Kazenstein. New York: Columbia University Press. Forthcoming

Betts, Richard K. 1977. Soldiers, Statesmen, and Cold War Crises Cambridge: Harvard University Press.

Blair, Clay. 1975. Silent Victory: The U.S. Submarine War Against Japan Philadelphia: J. B. Lippincott.

Bloom, William. 1990. Personal Identity, National Identity, and International Relations. Cambridge: The University Press.

$\rightarrow$ Cohen, Michael D., and Robert Axelrod. 1984. "Coping with Complexity: The Adaptive Value of Changing Utility." American Economic Review 74:30-42.

Douglas, Sholto, Lord of Kirtleside. 1966. Years of Command, vol. 2. London: Collins.

Evangelista, Matthew. 1988. Innovation and the Arms Race. Ithaca: Cornell University Press.

Evans, Peter B., Harold K. Jacobson, and Robert D. Putnam, eds. 1993. Double-Edged Diplomacy. Berkeley: University of California Press.

$\rightarrow$ Fearon, James D. 1995. "Rationalist Explanations for War." International Organization 49:379-414.

Finnemore, Martha, N.d. Defining National Interests in International Society. Ithaca: Cornell University Press. Forthcoming.

Frieden, Jeffry. 1991. "Invested Interests." International Organization 45:425-51.

Frieden, Jeffry. 1995. "Actors, Preferences, and International Relations." Presented at the annual meeting of the American Politica Science Association, Chicago.

George, Alexander. 1979. "Case Studies and Theory Development:
The Method of Structured, Focused Comparison." Diplomacy: New Approaches in History, Theory, and Policy, ed. Paul Gordon Lauren. New York: Free Press.

George, Alexander, and Timothy McKeown. 1985. "Case Studies and Theories of Organizational Decision Making." In Advances in Information Processing in Organizations, vol. 2, ed. Robert Coulam and Richard Smith. Greenwich: JAI Press.

$\rightarrow$ Glaser, Charles. 1994-95. "Realists as Optimists: Cooperation as Self-Help." International Security 19:50-90.

Goldstein, Judith. 1993. Ideas, Interests, and American Trade Policy. Ithaca: Cornell University Press.

$\rightarrow$ Gowa, Joanne. 1986. "Anarchy, Egoism, and Third Images.” International Organization 40:167-85.

Greif, Avner. 1994. "Cultural Beliefs and the Organization of Society: A Historical and Theoretical Reflection on Collectivist and Individualistic Societies." Journal of Political Economy 102:912-41.

Grieco, Joseph M. 1990. Cooperation Among Nations: Europe, America, and Non-Tariff Barriers to Trade. Ithaca: Cornell University Press.

Grieco, Joseph M., Robert Powell, and Duncan Snidal. 1993. "The Relative Gains Problem for International Relations." American Political Science Review 87:729-43.

Haas, Peter, ed. 1992. Knowledge, Power and International Policy Coordination, special issue, International Organization 46 (Winter 1992).

$\rightarrow$ Haggard, Stephan, and Beth A. Simmons. 1987. "Theories of International Regimes." International Organization 41:491-517.

Hallion, Richard P. 1989. Strike from the Sky: The History of Battlefield Air Attack 1911-1945. Washington, DC: Smithsonian Institution Press.

Halperin, Morton H. 1974. Bureaucratic Politics and Foreign Policy. Washington, DC: Brookings.

Higham, Robin. 1966. The Military Intellectuals in Britain: 1918-1939. New Brunswick: Rutgers University Press.

Hinsley, F.H. 1979. British Intelligence in the Second World War: Its Influence on Strategy and Operations: Vol. I. New York: Cambridge University Press

Jervis, Robert. 1976. Perception and Misperception in International Politics. Princeton: Princeton University Press.

Jervis, Robert. 1978. "Cooperation Under the Security Dilemma." World Politics 30:167-214.

Jervis, Robert, Richard Ned Lebow, and Janice Gross Stein, eds. 1985. Psychology and Deterrence. Baltimore: Johns Hopkins University Press.

$\rightarrow$ Jervis, Robert. 1988. "Realism, Game Theory, and Cooperation." World Politics 40:317-49.

Johnson, Chalmers. 1982. MITI and the Japanese Miracle. Palo Alto: Stanford University Press.

$\rightarrow$ Johnson, James. 1993. "Is Talk Really Cheap? Prompting Conversation Between Critical Theory and Rational Choice." American Political Science Review 87:74-86.

$\rightarrow$ Johnston, Alastair Iain. 1995a. "Thinking about Strategic Culture." International Security 19:32-64.

Johnston, Alastair Iain. 1995b. Cultural Realism: Strategic Culture and Grand Strategy in Chinese History. Princeton: Princeton University Press.

Jones, Neville. 1987. The Beginnings of Strategic Air Power: A History of the British Bomber Force, 1923-1939. London: Frank Cass

Katzenbach, Edward L., Jr. 1958. "The Horse Cavalry in the Twentieth Century." Public Policy 8:120-49.

Katzenstein, Peter, ed. 1978. Between Power and Plenty. Madison: University of Wisconsin Press.

Katzenstein, Peter, ed. N.d. The Culture of National Security: Norms, Identity, and World Politics. New York: Columbia University Press. Forthcoming.

Keegan, John. 1993. A History of Warfare. New York: Knopf.

Keohane, Robert O. 1989. International Institutions and State Power. Boulder: Westview Press.

Khong, Yuen Foong. 1992. Analogies at War: Korea, Munich, Dien Bien Phu and the Viet Nam Decisions of 1965. Princeton: Princeton University Press.

Kier, Elizabeth. N.d. Imagining War: French and British Military Doctrine Between the Wars. Princeton: Princeton University Press. Forthcoming.

Krasner, Stephen D. 1972. “Are Bureaucracies Important? (Or Allison Wonderland)." Foreign Policy 7:159-79. 
Krasner, Stephen. 1978. Defending the National Interest. Princeton: Princeton University Press.

Krepinevich, Andrew F., Jr. 1986. The Army in Viet Nam. Baltimore: Johns Hopkins University Press.

Kreps, David M. 1990. Corporate Cultures and Economic Theory. In Perspectives on Positive Political Economy, ed. James E. Alt and Kenneth A. Schepsle. New York: Cambridge University Press.

Kuhn, Thomas S. 1970. The Structure of Scientific Revolutions, $2 \mathrm{~d}$ ed. Chicago: University of Chicago Press.

Kupchan, Charles. 1994. The Vulnerability of Empire. Ithaca: Cornell University Press.

Lake, David. 1988. Power, Protection and Free Trade. Ithaca: Cornell University Press.

$\rightarrow$ Legro, Jeffrey W. 1994. "Military Culture and Inadvertent Escalation." International Security 18:108-42.

Legro, Jeffrey W. 1995a. Cooperation Under Fire. Ithaca: Cornell University Press.

Legro, Jeffrey W. 1995b. "Which Norms Matter?: Revisiting the "Failure" of Internationalism in World War II." Presented at the annual meeting of the American Political Science Association, Chicago.

$\rightarrow$ Levitt, Barbara, and James G. March. 1988. "Organizational Learning." Annual Review of Sociology 14:319-40.

Levy, Jack S. "Preferences, Constraints, and Choices in July 1914." International Security 15:151-87.

Lipson, Charles. 1985. "International Cooperation in Economic and Security Affairs." World Politics 38:1-23.

Lowi, Theodore. 1969. The End of Liberalism: Ideology, Policy and the Crisis of Public Authority. New York: Norton.

$\rightarrow$ Maoz, Zeev, and Bruce Russett. 1993. "Normative and Structural Causes of Democratic Peace, 1946-1986." American Political Science Review 87:624-38.

Martin, Lisa L. 1992. Coercive Cooperation: Explaining Multilateral Economic Sanctions. Princeton: Princeton University Press.

$\rightarrow$ Mearsheimer, John. 1994/95. "The False Promise of International Institutions." International Security 19:5-49.

Miller, Benjamin. 1992. "Explaining Great Power Cooperation in Conflict Management." World Politics 45:17-26.

Milner, Helen. 1988. Resisting Protectionism: Global Industries and the Politics of International Trade. Princeton: Princeton University Press.

$\rightarrow$ Milner, Helen. 1992. "International Theories of Cooperation Among Nations: Strengths and Weaknesses." World Politics 44:466-96.

Moravcsik, Andrew. 1992. "Liberalism and International Relations Theory." Center for International Affairs Working Paper Series No. 92-6. Cambridge: Harvard University.

$\rightarrow$ Morrow, James D. 1988. "Social Choice and System Structure in World Politics." World Politics 41:75-97.

$\rightarrow$ Morrow, James D. 1989. "Capabilities, Uncertainty, and Resolve: A Limited Information Model of Crisis Bargaining." American Journa of Political Science 33:941-72.

Murray, Williamson. 1980. "British and German Air Doctrine between the Wars." Air University Review 31:39-57.

Murray, Williamson. 1985. The Luftwaffe. Baltimore: Nautical and Aviation Publishing Co. of America.

Murray, Williamson. 1992. "The Influence of Pre-War Anglo-American Doctrine on the Air Campaigns of the Second World War." In The Conduct of the Air War in the Second World War, ed. Horst Boog. New York: Berg.

Nau, Henry R. 1993. "Identity and International Politics: An Alternative to Neorealism." Presented at the annual meeting of the American Political Science Association, Washington, D.C

$\rightarrow$ Ouchi, William G., and Alan L. Wilkins. 1985. "Organizational Culture." Annual Review of Sociology 11:457-83.

Oye, Kenneth A., ed. 1986. Cooperation Under Anarchy. Princeton: Princeton University Press.

Oye, Kenneth A. 1992. Economic Discrimination and Political Exchange: World Economy in the 1930s and 1980s. Princeton: Princeton University Press.

Pedersen, Jesper S., and Jesper S. Sorenson. 1989. Organisation Cultures in Theory and Practice. Aldershot, UK: Gower

Posen, Barry. 1984. The Sources of Military Doctrine. Ithaca: Cornell University Press.

Posen, Barry. 1991. Inadvertent War. Ithaca: Cornell University Press.

Powell, Robert. 1990. Nuclear Deterrence Theory: The Problem of Credibility. Cambridge: the University Press.
Powell, Robert. 1991. "Absolute and Relative Gains in International Relations Theory." American Political Science Review 85:1303-21.

Powell, Robert. 1994. "Anarchy in International Relations Theory." International Organization 48:313-34.

Powers, Barry D. 1976. Strategy Without Slide-Rule: British Air Strategy, 1914-1939. London: Croom Helm.

$\rightarrow$ Putnam, Robert. 1988. "Diplomacy and Domestic Politics: The Logic of Two-Level Games." International Organization 42:427-60.

Quester, George. 1966. Deterrence Before Hiroshima. New York: Wiley.

Rhodes, Edward. 1994. "Do Bureaucratic Politics Matter?" World Politics 47:1-41.

Rogowski, Ronald. 1989. Commerce and Coalitions. Princeton: Princeton University Press.

Rosen, Stephen Peter. 1991. Winning the Next War: Innovation and the Modern Military. Ithaca: Cornell University Press.

Rosen, Stephen Peter. 1995. "Military Effectiveness: Why Society Matters." International Security 19:5-31.

Ruggie, John G. 1982. "International Regimes, Transactions, and Change: Embedded Liberalism in the Postwar Economic Order." International Organization 36:379-415.

Russett, Bruce. 1993. Grasping the Democratic Peace. Princeton: Princeton University Press.

Schein, Edward. 1985. Organizational Culture and Leadership. San Francisco: Jossey-Bass.

Schelling, Thomas C. 1960. The Strategy of Conflict. Cambridge: Harvard University Press.

Sigal, Leon. 1988. Fighting to a Finish: The Politics of War Termination in the United States and Japan, 1945. Ithaca: Cornell University Press. Smith, Malcolm. 1984. British Air Strategy Between the Wars. Oxford: Clarendon.

Snidal, Duncan. 1986. "The Game Theory of International Politics.” In Cooperation under Anarchy, ed. Kenneth A. Oye. Princeton: Princeton University Press.

Snyder, Jack. 1984. The Ideology of the Offensive. Ithaca: Cornell University Press

Snyder, Jack. 1991. Myths of Empire. Ithaca: Cornell University Press. Spaight, J. M. 1947. Air Power and War Rights. 3d ed. London: Longmans, Green.

Stein, Arthur A. 1990. Why Nations Cooperate: Circumstance and Choice in International Relations. Ithaca: Cornell University Press.

Stigler, George J., and Gary S. Becker. 1977. "DeGustibus Non Est Disputandum." American Economic Review 67:76-90.

Terraine, John. 1985. The Right of Line: The Royal Air Force in the European War 1934-1945. London: Hodder and Stroughton.

Tilly, Charles. 1984. Big Structures, Large Processes, Huge Comparisons. New York: Russell Sage Foundation.

Travers, Tim. 1987. The Killing Ground: The British Army, the Western Front, and the Emergence of Modern Warfare, 1900-1918. London: Allen \& Unwin.

Tress, Harvey B. 1988. British Strategic Bombing Policy through 1940: Politics, Attitudes, and the Formation of a Lasting Pattern. Lewiston, NY: Edwin Mellen.

Tullock, Gordon. 1962. "Economic Imperialism." In The Theory of Public Choice, ed. James M. Buchanan and Robert D. Tollison. Ann Arbor: University of Michigan Press.

Van Evera, Stephen. 1984. "Causes of War." Ph.D. diss., University of California, Berkeley.

Van Evera, Stephen. 1986. "Why Cooperation Failed in 1914." In Cooperation under Anarchy, ed. Kenneth A. Oye. Princeton: Princeton University Press.

$\rightarrow$ Verba, Sidney. 1961. "Assumptions of Rationality and Non-rationality in Models of the International System." World Politics 14:93-117.

Völker, Karl-Heinz, ed. 1968. Dokumente und Dokumentarfotos zur Geschichte der Deutschen Luftwaffe. Stuttgart: Deutsche Verlags Anstalt.

Wagner, R. H. 1991. "Nuclear Deterrence, Counterforce Strategies, and the Incentive to Strike First." American Political Science Review 85:727-50.

Waltz, Kenneth N. 1979. Theory of International Politics. Reading, MA: Addison-Wesley.

$\rightarrow$ Waltz, Kenneth N. 1993. "The Emerging Structure of International Politics." International Security 18:44-79.

Wark, Wesley. 1985. The Ultimate Enemy: British Intelligence and Nazi Germany, 1933-1939. Ithaca: Cornell University Press. 
Webster, Charles, and Noble Frankland. 1961. The Strategic Air Offensive, 1939-1945. London: HMSO.

Wendt, Alexander. 1992. "Anarchy Is What States Make of It: The Social Construction of Power Politics." International Organization 46:391-425.

$\rightarrow$ Wendt, Alexander. 1994. "Collective Identity Formation and the International State." American Political Science Review 88:384-98.
Wilson, James Q. 1989. Bureaucracy: What Government Agencies Do and Why They Do It. New York: Basic Books.

Wolfers, Arnold. 1962. Discord and Collaboration. Baltimore: Johns Hopkins University Press.

Zisk, Kimberly Marten. 1993. Engaging the Enemy: Organization Theory and Soviet Military Innovation, 1955-1991. Princeton: Princeton University Press. 